\title{
İklim Değişikliği Odaklı Politika Üretim ve Planlama Süreçlerinde Bilim-Politika Arayüzlerinin Yeri: İstanbul ve İzmir Kalkınma Ajansları
}

\section{The Science-Policy Interfaces in Climate Change-Related Policymaking and Planning Processes: Istanbul and Izmir Development Agencies}

\author{
iD Mehmet Eroğlu, ${ }^{1}$ (i) Aslı Öğüt Erbil ${ }^{2}$ \\ ${ }^{1}$ Istanbul Teknik Üniversitesi Sosyal Bilimler Enstitüsü, Bilim, Teknoloji ve Toplum Yüksek Lisans Programı, İstanbul \\ ${ }^{2}$ İstanbul Teknik Üniversitesi Fen Edebiyat Fakültesi, İnsan ve Toplum Bilimleri Bölümü, İstanbul
}

\section{ÖZ}

Bu çalışma, iklim değişikliğine dair politika üretme ve planlama süreçlerinde, bilgi üreticiler ve politika yapıcılar/plancıların etkileşim kurabilmeleri için oluşturulan bilim-politika arayüzlerine odaklanmaktadır. Çalışmada, iklim değişikliği tehdidine karşı etkin politikalar/planlar geliştirebilmek için bilgi üreticiler ve politika yapıcılar/plancıların birlikte bilgi, politika ve aksiyon ürettikleri “ortak üretim temelli bilim-politika arayüzleri”nin kurulması gerektiği iddia edilmektedir. Araştırma iki ana bölümden oluşmaktadır. Öncelikle, "bilgi”, "bilimsel bilgi" ve "bilim-politika arayüzleri" kavramları bağlamında teorik çerçeve sunulmaktadır. Sonrasında, bilim-politika arayüzlerinin pratikteki karşıı̆ı̆ı araştırmak üzere, İstanbul Kalkınma Ajansı (ISTKA) ve İzmir Kalkınma Ajansı (IZKA)'nın incelendiği vaka çalışmasının sonuçları tartışılmaktadır. Bu çalışmada, iZKA'nın iklim değişikliğini faaliyetlerinin merkezine yerleştirip konuya dair etkin bilim-politika arayüzleri oluşturduğu, iSTKA'nın ise iklim değişikliğini ancak diğer öncelik alanları içerisine bir "ortak yarar" olarak dahil ettiği ve iklim değişikliğine yönelik bilim-politika arayüzleri faaliyetlerinin iZKA'ya kıyasla yetersiz kaldığı tespit edilmiştir.

Anahtar sözcükler: Bilim-politika arayüzü; Bilim, Teknoloji ve Toplum; iklim değişikliği; İstanbul Kalkınma Ajansı; İzmir Kalkınma Ajansı; ortak üretim.

\begin{abstract}
This study focuses on the science-policy interfaces established for knowledge producers and policymakers/planners to interact in policymaking and planning processes regarding climate change. The study claims that in order to develop effective policies/plans against the threat of climate change, it is necessary to create "coproduction-based science-policy interfaces" in which knowledge producers and policymakers/planners produce knowledge, policy, and action together. The exploration is divided into two main parts. Primarily, the theoretical framework of the study in the context of the concepts of "knowledge", "scientific knowledge", and "science-policy interfaces" is presented. Afterward, to investigate the science-policy interfaces in practice, the results of the case study, which examines the Istanbul Development Agency (ISTKA) and the Izmir Development Agency (IZKA), are discussed. The findings of this study demonstrate that IZKA prioritizes climate change and creates effective science-policy interfaces regarding climate change-related issues, whereas ISTKA regards climate change only as a "co-benefit" within the other priority areas of the agency and, at least compared to IZKA, its activities on climate change focused science-policy interfaces are passive and insufficient.

Keywords: Science-policy interface; Science, Technology and Society; climate change; Istanbul Development Agency; Izmir Development Agency; co-production.
\end{abstract}

Bu makale, İstanbul Teknik Üniversitesi, Bilim, Teknoloji ve Toplum Yüksek Lisans Programı’nda, Doç. Dr. Aslı Öğüt Erbil danışmanlığında yürütülen, Mehmet Eroğlu’nun “A study of the science-policy interfaces in climate change policymaking: Izmir and Istanbul Development Agencies" başlıklı yüksek lisans tezinden kısmen yararlanılarak üretilmiştir.

Geliş tarihi: 01.12.2020 Kabul tarihi: 17.06.2021

Online yayımlanma tarihi: 05.07.202I

İletişim: Mehmet Eroğlu

e-posta: eroglumeh@itu.edu.tr 


\section{Giriş}

Planlama gibi bilim-politika-uygulama arasında köprü kuran disiplinlerde doğal ve önemli bir süreç olarak görülen, bilimsel bilgi temelli politikaların üretilmesi ve uygulanmasına yönelik talep ve ihtiyaç, son yıllarda birçok alanda artış göstermektedir. Bu talep ve ihtiyacı karşılamak üzere geliştirilen "bilim-politika arayüzü (science-policy interface)" kavramı, bilgi üreticiler ve politika yapıcılar arasında kurulan her türlü ortaklık ve işbirliğine işaret eder. Bilim-politika arayüzü kavramının özellikle önem kazandığı alanlardan bir tanesi de küresel iklim değişikliğidir. Ülkelerin sürdürülebilir olmayan politik ve ekonomik faaliyetlerinin bir sonucu olarak iklim değişikliği, toplumsal ve ekolojik hayat aleyhine ciddi tehditler oluşturmaktadır. Bu tehditlerle mücadele edecek yeni ve daha etkin iklim politikalarının tanımlanmasında ve mevcut politikaların irdelenmesinde bilim-politika arayüzü faaliyetleri giderek yaygınlaşmaktadır.

Bilim-politika arayüzleri oluşturulurken kimi zaman bilgi üreticilerin kimi zamansa politika yapıcıların rollerine fazla vurgu yapıldığı ya da iki grup arasında dikey hiyerarşilerin oluşturulduğu gözlemlenmektedir. Bilim, Teknoloji ve Toplum (BTT) çalışmaları perspektifinde gelişen bu makalede ise, bilgi üreticiler ve politika yapıcıların hiyerarşilerden bağımsız olarak, sürekli etkileşim ve işbirliği halinde, birlikte bilgi, politika ve eylem ürettikleri ortak üretim temelli bilim-politika arayüzleri ideal arayüzler olarak benimsenmiştir. Bu bağlamda küresel iklim değişikliği gibi çok boyutlu ve karmaşık bir olgunun etkilerini azaltabilecek ve sonuçlarına uyum sağlamayı kolaylaştıracak politikaların üretilmesi ve uygulanması için ortak üretim temelli bilim-politika arayüzlerinin kurulmasının, geliştirilmesinin, etkin hale getirilmesinin ve kalıcı kılınmasının kaçınıımaz olduğu öne sürülmektedir.

İ̧aret edilen arayüzlerin öneminden hareketle, bu çalışmanın amacı, Türkiye'deki iki kalkınma ajansının (KA) -i̇stanbul Kalkınma Ajansı (ISTKA) ve İzmir Kalkınma Ajansı (IZKA)iklim değişikliği ile ilişkili faaliyetleri üzerinden bilim-politika arayüzü yaklaşımlarını ve uygulamalarını incelemektir. Her iki ajansın iklim değişikliğine ilişkin mevcut yaklaşım ve deneyimlerinin analiz edilmesi ve iki ayrı vaka irdelemesi sonunda elde edilen bulgular ışığında, yerelde iklim değişikliğiyle baş edebilecek etkin bir politika anlayışının ve planlama pratiğinin nasıl kurgulanabileceğine dair ipuçlarının da paylaşılması hedeflenmektedir.

Dört bölümden oluşan makalede giriş bölümünü takiben çaıışmanın kuramsal çerçevesi sunulmaktadır. Üçüncü bölümde, bilim-politika arayüzlerinin gerçek hayatta nasıl karşılık bulduklarını araştırabilmek için vaka çalışması olarak seçilen isTKA ve IZKA incelemelerinin sonuçları paylaşlacak ve tartışılacaktır. Sonuçlar ise dördüncü bölümde ortaya koyulacaktır.

\section{Kuramsal Çerçeve}

Bu bölümde makalenin kuramsal çerçevesinin tanımlanması için, öncelikle bilimsel bilgi ve iklim politikaları ilişkisi, daha sonra çalışmanın bilim-politika arayüzü anlayışı ve son olarak bu arayüzlerin oluşmasını engelleyen veya zorlaştıran bariyerler ele alınmaktadır.

\section{I. Bilimsel Bilgi ve Bilimsel Bilginin İklim Değişikliği Politikalarındaki Yeri}

İklim değişikliği, Hükümetlerarası İklim Değişikliği Paneli [Intergovernmental Panel on Climate Change (IPCC)] tarafindan, "doğal dönüşümlerden ya da insan faaliyetlerinden kaynaklı olarak iklimde meydana gelen ve uzun süre kalıcı olan her türlü değişiklik" olarak tanımlanmaktadır (IPCC, 2007: 30). Buna bağlı olarak, iklim değişikliğine ilişkin bilimsel bilgi, küresel, ulusal, bölgesel ve yerel iklim sisteminin yapısına dair modeller oluşturan, örüntüler tespit eden, risk değerlendirmelerinde bulunan ve geleceğe yönelik projeksiyonlar çizen bilimsel çalışmaların sonuçlarını işaret etmektedir.

İklim değişikliği söz konusu olduğunda bilimsel bilgi ve politika yapımı arasında doğrudan bir ilişkinin gerekliliği göze çarpmaktadır. Bu durumun temel sebebi, bilimsel bilgi olmadan iklim değişikliğine yönelik doğru analizler gerçekleştirebilmenin ve iklim değişikliğine neden olan sera gazlarını azaltacak veya iklim değişikliği nedeniyle oluşacak yeni koşullara uyum sağlamayı kolaylaştıracak etkin politikalar geliştirebilmenin mümkün olmamasıdır. Başka bir ifadeyle, karar almak için tek başına yeterli olmamasına rağmen, alınan kararların daha nitelikli olmasına yardımcı olduğu için (Cortner, 2000: 28), iklim değişikliği ile doğrudan veya dolaylı olarak ilişkili bütün karar verme süreçlerinin iklim biliminin bulguları ile desteklenmesi, yani iklim politikaları ve planlarının bilimsel bilgi temelli olması, önemli görülmektedir.

Bilimsel çalışmaların iklim ve çevre krizine dair tespitlerinin ve önerilerinin politika dünyasına aktarılabilmesi için, özellikle 20. yüzyılın son çeyreğinden itibaren, birçok faaliyet gerçekleştirilmiştir. "Birleşmiş Milletler (BM) İnsan Çevresi Konferansı (1972)", "Birinci Dünya İlim Konferansı (1979)", "BM Çevre ve Kalkınma Konferansı (1992)", 1997 yılında 193 ülke tarafından imzalanan "Kyoto Protokolü" ve 12 Aralık 2015 tarihinde kabul edilen ve kabul edildiği ilk gün 175 ülke tarafından imzalanan "Paris Anlaşması" bazı önemli kırılım noktaları olarak gösterilebilir. İklim bilimi ve iklim politikası arasındaki kurumsallaşmaya yönelik belki de en önemli adım ise 1988 yılında Dünya Meteoroloji Örgütü ve Birleşmiş Milletler Çevre Programı (BMÇP) işbirliğinde IPCC'nin kurulmasıdır. IPCC, kurulduğu günden bu yana iklim değişikliğine ilişkin somut bilimsel bulguları bir araya getirerek karar vericiler başta olmak üzere toplumun farklı kesimlerine aktarılması ve açıklanması için çalışmaktadır. 
Bütün bu gelişmelere rağmen, hem uluslararası hem de ulusal ölçekte, politika yapıcıların ve karar vericilerin bilimsel çalışmaların iklim değişikliğine ilişkin önerdiği çözüm önerilerini hayata geçirmede yeterince istekli ya da etkili davranmadıkları görülmektedir. Başka bir deyişle, iklim bilimi ile iklim politikası arasında mesafeli bir duruş süregelmektedir (lyalomhe vd., 20I3; Jasanoff, 20II; Moser ve Dilling, 20II; O'Brien, 20I3). Bu mesafeye dikkat çekmek ve iklim biliminin bulgularının politikaya dönüşmesini kolaylaştırmak için IPCC "Politika Yapıcılar İçin Özet” raporlar yayınlamaktadır. Benzer şekilde, BMÇP'nin Bilim-Politika Arayüzünün Güçlendirilmesi raporunda, bilimsel faaliyetlerin politika yapıcılar tarafından anlaşılmadığı veya kullanılmadığı ve bu durumun bilgi üreticiler ve politika yapıcılar arasındaki işbirliği fırsatlarını olumsuz etkilediği iddia edilmektedir (BMÇP, 20I7). Farklı ülkeler ve bölgelere odaklanan çalışmalarda da politika yapıcıların iklim değişikliğine ilişkin bilimsel bilgileri politikaya ve aksiyona dönüştürmekte çeşitli sebeplerle yeterince başarılı olamadıklarına dikkat çekilmektedir (bkz. Compston ve Bailey, 2008; Haug vd., 20 I0; Newman ve Head, 2015). Türkiye için yapılan araştırmalarda da, ulusal, yerel ölçekte ve sivil toplum düzeyinde iklim değişikliğine yönelik yeterli ve etkin adımların atılmadığı ortaya koyulmaktadır (bkz. Adaman ve Arsel, 2016; Gedikli ve Balaban, 2018; Turhan vd., 2016).

İklim biliminin bulgularının politikaya dönüştürülmesi gerekliliğinin iklim değişikliğinin çok boyutlu ve katmanlı yapısı ile birlikte düşünülmesi yerinde olacaktır. Çünkü bu yapı, konuya ilişkin politikaların geliştirilmesinde de aynı türde katmanlaşma/etkileşim gerektirmektedir. Bu süreçte, ulus-altı ölçekler olan bölge ve kent düzeyinin yüksek bir liderlik potansiyelinin olduğuna dikkat çekilmektedir (Bulkeley, 20l I: I-2). Bu potansiyelin etkili olmasında geliştirilen yönetişim modellerinin önemi vurgulanmakta ancak söz konusu modellerin öncelikle iklim biliminin ortaya koyduğu bilgileri eyleme geçirmede bir tercüman görevi üstlenmesi gerektiği de belirtilmektedir. Bunun en iyi örneği IPCC'nin Beşinci Değerlendirme Raporu'nda görülmektedir. Beşinci Değerlendirme Raporu-II. Çalışma Grubu'nda (IPCC, 20I4) ve BMÇP Uyum Açığı Raporu'nda (20l4) planlama ve uygulamayı etkileyen “bilgi boşlukları”nın bulunduğu ifade edilmektedir. Söz konusu raporlarda bilgi boşluklarının sadece bilgi parçalarının karar alma süreçlerine eklenmesi ile giderilemeyeceği, bilgi/ bilgi sistemlerinin kamu politikalarına entegrasyon ve uyumunun sağlanması gerektiği ifade edilmektedir (Ryan ve Bustos; 2019: 1298). Ayrıca söz konusu boşluğun giderilmesi talebinin sadece bilgi üreticiler ve karar vericiler arasında bir konu olmadığı, bu talebin küresel iklim eyleminin katılımcıları, özellikle bu hareketin liderliğini yapan genç nesil arasında, ana vurguyu oluşturduğu görülmektedir. Örneğin, Colorado Mines Üniversitesi öğrencisi Kirsten Blagg "[G]erçek bilgiye sahip bilim insanlarının dinlenmemesi oldukça sinir bozucu" derken (Nature, 2019), küresel iklim eyleminin sembolü

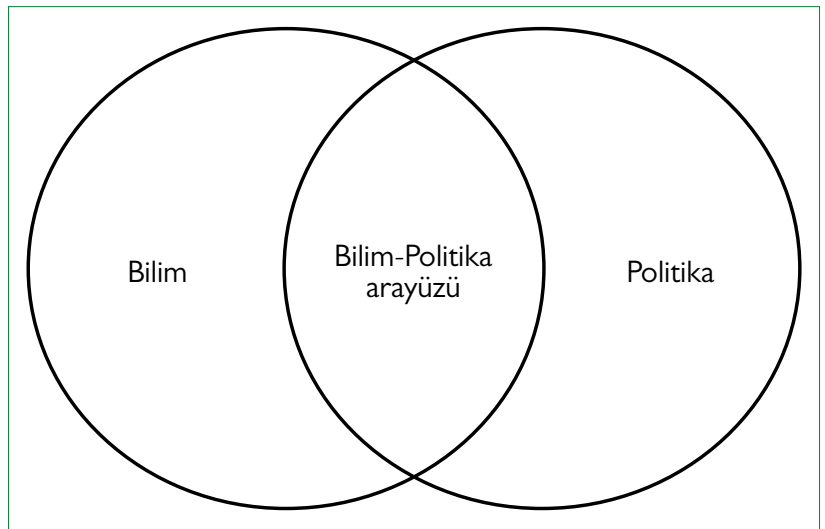

Şekil I. Bilim-politika arayüzü.

haline gelen Greta Thunberg 2019 yılında ABD-Temsilciler Meclisine yazılı olarak sunduğu görüşünde "Bilim insanlarını dinlemenizi istiyorum. Ve bilimin arkasında birleşmenizi istiyorum. Ve sonra harekete geçmenizi istiyorum" diye yazarak (Thunberg, 2019) politika ve karar vericilerin bu boşluğu doldurmada daha fazla çaba göstermeleri gerektiğini belirtmiştir.

Yukarıda açıklandığı üzere, iklim değişikliğine yönelik politikaların etkin olabilmesi için iklim biliminin bulgularından daha doğru bir şekilde yararlanılması gerekmektedir. Dolayısıyla iklim bilimi ve iklim politikası arasında bilinçli bir şekilde kurgulanmış bir arayüz oluşturulması iki dünya arasındaki etkileşimin geliştirilmesi açısından önem taşımaktadır. Bir sonraki başlıkta bilim-politika arayüzüne dair detaylar ve bu çalışmanın hangi tür bilim-politika arayüzünü etkin iklim değişikliği politikası geliştirilmesinde uygun bulduğu paylaşılmaktadır.

\subsection{Bilim-Politika Arayüzleri}

Bilim ve politika dünyaları arasındaki kurumsal farklılıklar ve paradigma uyuşmazlıkları nedeniyle mutlak ve değişmez bir bilim-politika arayüzü tanımı yapmak güçtür (lyalomhe vd., 20I3). Bununla birlikte, en genel anlamda bilim dünyası ve politika dünyası arasındaki kesişimi ifade eden bilim-politika arayüzleri (Şekil I), Van den Hove’a göre, "politika sürecindeki bilim insanları ve diğer aktörler arasındaki ilişkileri kapsayan ve karar alma sürecini zenginleştirmek amacıyla bilginin karşılıklı transferine, ortak evrimine ve ortak inşasına zemin hazırlayan sosyal süreçler" olarak tanımlanabilir (Van den Hove, 2007: 8I4-8I5). Bilim dünyası ve politika dünyası arasındaki iletişim, bilimsel makale okumak, yüz yüze görüşmeler gerçekleştirmek, bilim kurulları oluşturmak, konferanslar düzenlemek, ortak çalışma projeleri yürütmek gibi birçok farklı kanal üzerinden gerçekleşebilir (Choi vd., 2016: 3; Mitton vd., 2007: 744). Ancak, bilim-politika arayüzü kavramı, bilgi üreticiler ve politika yapıcıların sosyal süreçlerle karşılıklı etkileşimini işaret ederek, pasif ve dolaylı yoldan kurulan ilişki türlerinden ayrılmaktadır. Başka bir ifadeyle, bu arayüzler, sözü edilen iki grubun etkileşime girmesi ve işbir- 
likleri gerçekleştirmesi ihtiyacını karşılamak üzere oluşturulan ortak faaliyet alanları ve süreçlerdir.

Bu makalenin odak noktası ise özellikle iklim değişikliğine ilişkin faaliyetler kapsamında oluşturulan bilim-politika arayüzleridir. Bu odaklanmanın temel gerekçesi, bir önceki başlıkta ifade edildiği üzere, iklim değişikliği gibi karmaşık ve çok boyutlu bir fenomen söz konusu olduğunda, bilimsel bilgi üreticilerin ve politika yapıcıların birbirleriyle etkileşim halinde olmaya ve ortak çalışmalar gerçekleştirmeye ihtiyaç duyuyor olmalarıdır. Bilim-politika arayüzlerinin iklim değişikliğine ilişkin bilimsel bilgiyi gözeten kapsayıcı, bütünsel ve uygulanabilir politikalar geliştirilebilmesine imkân sağlayacağı öngörülmektedir.

Dünya üzerinde çeşitli ölçeklerde bilim-politika arayüzü faaliyetleri sürdürülmektedir. Bu faaliyetler incelendiğinde, bilim-politika arayüzlerinin, resmi veya gayri resmi, birçok farklı formda oluşturulduğu görülmektedir. Örneğin, “IPCC”, “Biyolojik Çeşitlilik ve Ekosistem Hizmetleri Konulu Hükümetlerarası Bilim-Politika Platformu [Intergovernmental Science-Policy Platform on Biodiversity and Ecosystem Services (IPBES)]", Avrupa Komisyonu'na bağlı “Ortak Araştırma Merkezi” (Joint Research Centre)" ya da "Birleşmiş Milletler Çölleşme ile Mücadele Sözleşmesi Bilim-Politika Arayüzü (BMÇMS-BPA) [United Nations Convention to Combat Desertification Science-Policy Interface (UNCCD-SPI)]" birer bilim-politika arayüzü organizasyonudur. Özellikle "UNCCD-SPI”, 20I3 yılında II. Taraflar Konferansı'nda doğrudan "bilim-politika arayüzü” olarak kurulmuş ve takip eden konferanslarda da yenilenmeye devam etmiştir. Bu oluşumun temel amacı, çölleşme, arazi bozulması ve kuraklık konularında mevcut bilimsel değerlendirmeleri politika stratejisi önerilerine dönüştürerek bilim insanları ve politika yapıcılar arasındaki ilişkiyi geliştirmektir. Halihazırda UNCCDSPI, küresel olarak seçilmiş 10 bağımsız bilim insanı, bölgesel olarak aday gösterilmiş 5 bağımsı bilim insanı, 5 seçilmiş Bilim ve Teknoloji Komitesi (BTK) üyesi (bilim odaklı politika yapıcılar) ve 5 gözlemci organizasyon temsilcisinden oluşmaktadır (Şekil 2) (UNCCD, 202I). IPCC, IPBES ve UNCCD-SPI gibi kurumsal organizasyonlara ek olarak, politikacılar ve bilim insanlarını bir araya getiren araştırma projeleri, toplantılar veya atölye çalışmaları, hatta karşııklı bilgi ve deneyim alışverişine olanak sağladığı sürece bir bilim insanı ve politikacı arasındaki bir diyalog bilim-politika arayüzü olarak değerlendirilebilir. Örneğin, Akdeniz'deki iklim ve çevre değişikliğinin mevcut durumu ve bölge için yarattığı riskleri tartışmak üzere bilim insanları ve karar vericileri bir araya getiren 2 saatlik bir etkinlik de bilimpolitika arayüzü tanımına uygundur (bkz. MedECC, 20l8).

Bununla birlikte, BTT perspektifine göre, tek tip bir bilimpolitika arayüzü bulunmamakta, arayüzlerin kurgulanması ve sürdürülmesinde farklı yaklaşımlar yer alabilmektedir. Arayüz

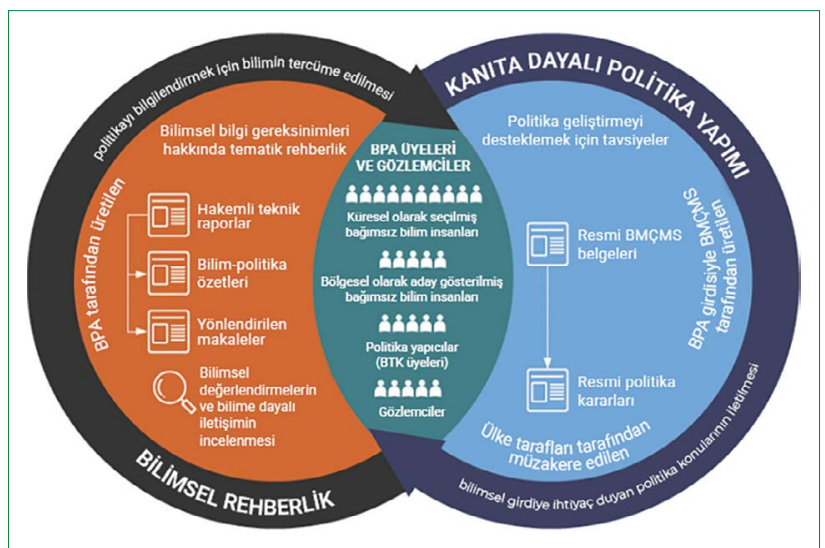

Şekil 2.Birleşmiş Milletler Çölleşme ile Mücadele Sözleşmesi Bilim-Politika Arayüzü (BMÇMS-BPA).'

BPA: Bilim-Politika Arayüzü; BTK: Bilim ve Teknoloji Komitesi; BMÇMS: Birleşmiş Milletler Çölleşme ile Mücadele Sözleşmesi.

modellerini farklılaştıran en önemli unsur, arayüzlerde etkileşime giren bilgi üreticiler ve politika yapıcılar arasındaki ilişkilerin niteliğidir. Politika yapıcıların baskın olduğu ve bilgi üreticilerin faaliyetlerini yönlendirdiği arayüzler olduğu gibi, bilgi üreticilerin hangi tür bilginin üretilmesi ve paylaşılması gerektiğine tek başlarına karar verdiği arayüzler de bulunmaktadır (Dilling ve Lemos, 20II; Dunn vd., 2018). Bu tür hiyerarşik arayüz modelleri, bilgi üreticiler ve politika yapıcılar arasında ilişki kurmakta ancak bu ilişkide eşitlik ve ortaklaşma gözetmemektedir. Son yıllarda, hiyerarşik modellere alternatif olarak geliştirilen "ortak üretim temelli bilim-politika arayüzleri” daha katılımcı-demokratik yapısı ve etkin sonuç elde etmeye odaklanmış olması ile dikkat çekmektedir (Dunn vd., 2018; Meadow vd., 20I5; Wall vd., 2017; Wan vd., 2020). Bu modeldeki "ortak üretim” kavramının anlamı kullanıldığı disipline göre değişkenlik gösterir. BTT çalışmalarında "bilimsel bilginin ve politik düzenin ortak evrimsel süreç içerisinde birlikte üretildiğine" (Jasanoff, 2004) dair epistemolojik bir anlama sahip olan "ortak üretim" kavramı, sürdürülebilirlik ya da kamu yönetimi çalışmalarında ise farklı paydaşların bir araya gelerek birbirleriyle bilgi, tecrübe ve değerlerini paylaşıp ortak çalışmalar ve üretimler gerçekleştirmesine işaret etmektedir (Wyborn vd., 2019). Bu farklı gibi görünen perspektiflerin bir araya getirildiklerinde ise birbirlerini besledikleri ve pekiştirdikleri görülmektedir. Bilim dünyası ve politika dünyası arasındaki sınırların düşünüldüğü kadar keskin olmadığını iddia eden BTT perspektifinin ortak üretim kavramı "bir normatif hedef ve analitik bakış açısı olarak yönetişim için bir temel oluşturmaktadır" (Wyborn, 2015: 56) (Şekil 3).

BTT perspektifinden türetilen "ortak üretim” kavramının daha iyi anlaşılabilmesi için, bir BTT düşünürü olan Jasanoff'un bilim dünyası ve politika dünyası arasındaki ilişkiye dair iki teorik

Bu şekil UNCCD-SPI'nin internet sitesinden tercüme edilerek alınmıştır. Görselin aslı için bkz.: https://knowledge.unccd.int/science-policy-interface/how-spi-works (Erişim tarihi: 27.04.2021). 


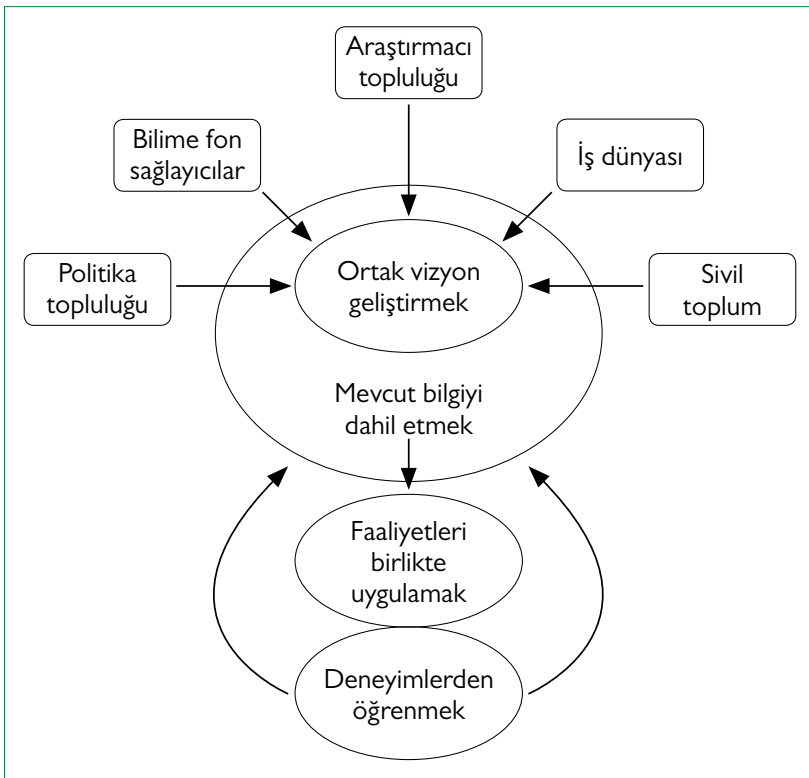

Şekil 3. Ortak bilgi ve aksiyon üretimini hedefleyen bir ortak tasarım modeli. $^{2}$

tespitinin paylaşılması yerinde olacaktır. Bunlardan birincisi, Jasanoff'un tekno-bilimsel bilginin ve bu bilginin üreticilerinin mutlak otorite olarak kabul edildiği "teknokratik yaklaşım" ve politik çıkarlara öncelik verilerek bilimsel bilginin önemsizleştirildiği “demokratik (popülist) yaklaşım” olarak nitelediği iki kuramsal modele yönelik eleştirisidir (Jasanoff, 1994: vii). Jasanoff'a göre, teknokratik ve popülist yaklaşımlar bilim ve politika arasındaki ilişkinin geliştirilebilmesi noktasında yetersiz olduğu için daha geniş bir perspektife ihtiyaç duyulmaktadır (Jasanoff, 1994: vii). Jasanoffun ikinci teorik katkısı ise, bilgi üreticiler ve politika yapıcılar arasındaki, fiziksel olmasa bile, entelektüel sınırlara ilişkindir. Bir yandan, politikacıların etkis ve baskısı altında kalabileceklerinden endişe ederek bilgi üreticilerin politika yapım sürecinin merkezinde olmasını, öte yandan bilgi üreticilerin tamamen politika yapım sürecinin dışında kalmasını eleştiren Jasanoff, bilgi üreticiler ve politika yapıcılar arasındaki ideal entelektüel mesafeyi şöyle formüle eder: "Politikayla ilgili bilim insanları politikaya yakın olmak ister, ancak çok yakın değil” (Jasanoff, 1994). Gieryn (1995) de, Jasanoff un bu görüşünü geliştirerek, bilgi üreticilerin politika yapıcılara olan mesafesinin "objektif ve otoriter olacak kadar uzak, faydalı olacak kadar yakın” (s. 439) olması gerektiğini savunur.

Sonuç olarak, ortak üretim modelini diğer arayüz modellerinden ayıran iki temel özellik vardır. Birincisi, iki grup arasındaki güç ilişkilerinin en aza indirilmeye çalışılmasıdır. İkincisi ise, bi- lim dünyası ve politika dünyasının aktörlerinin kendi alanlarında çalışmalar gerçekleştirip daha sonra bilgi transferi yapması yerine, faaliyetlerini sürekli etkileşim halinde mümkün olduğunca birlikte gerçekleştirmesidir. ${ }^{3}$ BTT literatürüne, özellikle de Jasanoff un (2004) ortak üretim çalışmalarına istinaden, bu çalışmada "ortak üretim temelli bilim-politika arayüzleri" içerik olarak tanımı benimsenen arayüzler olarak kabul edilmiştir. Açıklanan kavramsal çerçeve bağlamında, makalenin ortak üretim temelli bilim-politika arayüzleri yaklaşımı, bilgi üreticiler ve politika yapıcıların diyalogu esas alan devamlı bir iletişim halinde, işbirliği ve dayanışma ortamı kurarak, her türlü dikey hiyerarşiden bağımsız bir şekilde bilgiyi, politikayı ve eylemi birlikte ürettikleri bilim-politika arayüzleri olarak tanımlanabilir. Ortaya koyulan ortak üretim modeli, teknokratik ve popülist modellere bir alternatif olarak, bilimsel bilginin elzem kabul edildiği ancak tek ve mutlak belirleyici olarak kutsallaştırılmadığı bir yaklaşıma işaret etmektedir. İzleyen bölümde, ortak üretim modelleri de dahil olmak üzere, bilim-politika arayüzlerinin oluşturulması ve sürdürülmesinde karşılaşılan sorunlar ele alınmaktadır.

\subsection{Bilim-Politika Arayüzlerinin Kurulmasını Engelleyen veya Zorlaştıran Bariyerler}

Bilgi temelli politikalar ve planlar geliştirilmesi için bilgi üreticiler ve politika yapıcılar/plancılar arasında sürdürülebilir ilişkiler kurulması ihtiyacı hemen herkes tarafından kabul edilmektedir. Ancak, bu iki grubun bir araya geleceği bilim-politika arayüzlerinin kurulmasında ve sürdürülmesinde daima bazı problemler yaşanmakta ve ihtiyaç duyulan nitelikteki arayüzlerin kurulabilmesi ve sürdürülebilmesi için söz konusu problemlerin -veya faktörlerin- ele alınması zorunlu görülmektedir. Literatürde "bariyer" olarak adlandırılan söz konusu faktörler, bilim-politika arayüzüne dair çalışmalarda arayüzün işleyişini anlama ve geleceğini belirleme amacıyla da özel olarak ele alınmaktadır.

Bu bariyerler arasında belki de en önemlisi, genellikle farklı normlar ve kriterler ile hareket eden bilgi üreticiler ve politika yapıcıların terimlere, kavramlara, fikirlere ve olaylara bakış açıları örtüşmeyen iki ayrı epistemik topluluğun üyeleri olmaları, yani dünya görüşlerinin farklılık göstermesidir (Edelenbos vd., 20II: 683; Hegger vd., 2012: 52; Van Stigt vd., 2015: 168). Bir diğer kritik bariyer ise, bilimsel bilginin, özellikle de iklim değişikliği gibi çok boyutlu ve karmaşık bir fenomen söz konusu olduğunda, her zaman bazı belirsizlikler içeriyor olmasıdır (Van Stigt vd., 20I5: 168). Bilimsel çalışmalara içkin olan bu belirsizlikler, bilimsel çıktıların itibarsızlaşmasına sebebiyet vererek, bilimsel bilginin karar verme süreçlerinin dışında bırakılmasına yol açabilmektedir.

\footnotetext{
2 Bu model Silke Beck'in bir sunumundan tercüme edilmiş ve ortak üretim kavramını modelleyen bir örnek olarak paylaşılmıştır (bkz. Beck, 20।6).

3 Ortak üretim temelli bilim-politika arayüzleri ile diğer bilim-politika arayüzü modelleri arasındaki farkı net bir şekilde ortaya koyabilmek için, süregiden COVıD-I 9 pandemisiyle mücadele etmek adına T.C. Sağlık Bakanlığı tarafından oluşturulan Koronavirüs Bilim Kurulu ele alınabilir. Bu kurul pandemiyle ilgili atılacak politik adımlara bilimsel destek sağlaması için bünyesinde çeşitli tıp dallarından uzmanlar ve akademisyenler barındırmaktadır. Ancak, bu kurulun esas işlevi yalnızca tavsiye vermektir ve nihai kararlar politika ve bürokrasi aktörleri tarafından alınmaktadır. Herhangi bir karar verme yetkisi ya da yaptırım gücü olmayan kurul üyelerinin, "ortak üretim" sürecinin paydaşları olduğunu söylemek mümkün görünmemektedir. Dolayısıyla, Koronavirüs Bilim Kurulu bir "bilim-politika arayüzü”dür, ancak bilginin veya politikanın ortak üretiminden bahsedilemeyeceği için “ortak üretim temelli bilim-politika arayüzü” değildir.
} 
Bu iki bariyerin dışında, bilimin rasyonel karar alma süreçleri için bilgi sağlamasına rağmen doğası gereği politik olan karar alma süreçlerinde "sınırlı rasyonellik (bounded rationality)" ile hareket edilmesi (Van Stigt vd., 20I5: 168), her iki grubun kendi çalışmalarıyla meşgul olmalarından kaynaklı zaman kısıtlamaları, arayüzlerin finansal yönetim problemleri, politikacılar ile ortak çalışmalar yapmanın "bilimsel özerlik" ve "bilimsel güvenilirliğe” zarar vereceği düşüncesi (Ramos-Vielba vd., 20ı5) ve akademik başarının ağırlıklı olarak yayın bazlı geleneksel sistem ile ölçülmesi sonucunda bilgi üreticilerin akademi dışı ortaklıkları tercih etmemesi (Jacobson vd., 2004: 249) gibi başka bariyerler de mevcuttur.

Bu bariyerler, her iki grubun ortaklaşmaya istekli olduğu durumlarda bile, aralarındaki özsel farklılıkların bilim-politika arayüzlerinin kurulmasını zorlaştırabileceğini göstermektedir. Bariyerlerin üstesinden gelebilmek için, bilgi üreticiler ve politika yapıcıların mevcut ya da potansiyel engellerin farkında olarak etkileşim kurmaları ve diğer grubun özelliklerini, şartlarını ve kısıtlarını anlamaya çalışması gerekmektedir. Bu anlayışın geliştirilebilmesi için her iki grubun diline, bakış açısına ve uygulamalarına aşina olan aracı kişi ve kuruluşlardan yararlanılabilir. Literatürde, "bilgi aracısı" (Hering, 20l6), "bilgi iletişimcisi” (Bultitude vd., 20I2) ya da "sınır organizasyonları" (Guston, 1999) gibi farklı isimler alan bu arabulucular bilim dünyası ve politika dünyası arasındaki iletişimi kolaylaştırarak ve geliştirerek, hem bilimsel bilginin kullanılabilir ve uygulanabilir bir forma dönüştürülmesine hem de karar vericilerin cevap aradıkları soruların bilgi üreticilere açıklanmasına yardımcı olabilirler (Wang vd., 2014: 333).

\section{Vaka Çalışması: İstanbul ve İzmir Kalkınma Ajansları}

Bu makale kapsamında, iklim değişikliğine ilişkin bilim-politika arayüzlerinin gerçek hayatta nasıl kurulduklarını ve sürdürüldüklerini araştırabilmek için iSTKA ve iZKA vaka çalışması olarak seçilmiş ve incelenmiştir. KA'lar, bölgesel ve yerel kalkınmaya katkıda bulunmak için, ulusal politikalar ve yönelimleri de gözeterek, bölgesel düzeyde politikalar, projeler ve planlar geliştiren ara ölçek kurumlardır (Erbil ve Erbil, 2019). Kurulduğunda Devlet Planlama Teşkilatı, şu anda Sanayi ve Teknoloji Bakanlığı koordinasyonunda hem bölge içi hem de bölgeler arası gelişmişlik farkını minimize etmeyi hedefleyen KA'lar, bir yandan kamu kurumlarına, özel sektöre ve sivil toplum kuruluşlarına maddi ve teknik destek sağlar, diğer yandan da bu aktörler arasında işbirliğini geliştirir. Aynı zamanda, özellikle Yatırım Destek Ofislerinin faaliyetleri ile, bölgenin iş ve yatırım fırsatlarının ulusal ve uluslararası ölçekte tanıtımını yapar (T.C. Cumhurbaşkanlığı, 2018).

Bu araştırmada, KA'ların vaka çalışması olarak seçilmesindeki nedenlerden biri bilim-politika arayüzü oluşturma potansiyeli taşıması, diğeri de iklim değişikliğine yönelik politika geliştirme kapasitesine sahip olmasıdır. Birincil nedene ilişkin olarak, farklı ölçekler ve paydaşlar arasında ilişki kurma potansiyeline ve yetkisine sahip olan KA'ların, bu faaliyetlerini tasarlar ve hayata geçirirken çeşitli aktörlerle işbirliği gerçekleştirdiği söylenebilir. Üstelik KA’lar, görev tanımları gereği bilgi-temelli, uzun vadeli, teorik ve bütünsel planlar, projeler ve politikalar geliştirmeyi hedeflemektedir. Bu kapsamda, bilgi üreticilerle sıklıkla ve doğrudan etkileşim kuran KA'lar, bilim-politika arayüzlerini çalışmak için uygun kurumlar olarak düşünülmüştür.

İkincil neden ise, KA'ların ulusal/uluslararası ve yerel ölçekler arasında etkileşimi geliştirebilecek bir pozisyonda bulunmasıdır. Dünyada ve Türkiye'de iklim değişikliğine ilişkin etkin faaliyetlerin yürütülmesinde çok düzeyli ve çok aktörlü bir yönetişim politikasının gerekliliği sıklıkla ifade edilmektedir (Bulkeley, 20II). Uluslararası, ulusal, bölgesel ve yerel düzeyde geliştirilen politikaların etkinliğini ve uygulanabilirliğini artırmak için farklı düzeylerde yer alan aktörlerin birbiri ile etkileşim içinde çalışması öngörülmektedir. Bu süreçte her düzeyin kendi güçlü olduğu alanı öne çıkararak katkıda bulunması önemlidir (Smith, 2007; Sovacool ve Brown, 2009). Bu nedenle, ulusal ve yerel düzeyde atılacak adımlar kadar bölgesel düzeydeki adımlar da değer kazanmaktadır (Erbil ve Erbil, 2019). Dolayısıyla, KA’lar, küresel bir problem olan fakat etkilerini yerelde gösteren iklim değişikliğine yönelik çok katmanlı politikalar geliştirme, ulus ve kent ölçekleri arasında bağlantı kurma ve iklim değişikliği azaltım ve uyum faaliyetleri için gerekli sistem dönüşümüne yönelik proje geliştirme kapasitesine sahip kurumlar olarak değerlendirilmişlerdir.

Türkiye'de faaliyet gösteren $26 \mathrm{KA}$ arasından iSTKA ve iZKA'nın seçilmesinin ise iki temel gerekçesi vardır. Birincisi, yüksek nüfus yoğunluğuna sahip ve Türkiye ekonomisinde kritik yerleri olan İstanbul ve İzmir bölgelerinin iklim değişikliğine karşı oldukça kırılgan olmasıdır (Abadie vd., 2016). İkinci neden ise KA'lar arasında finansal ve insan kaynakları açısından önde gelen iki kurum olan iSTKA ve IZKA'nın iklim değişikliği vizyonlarının ve buna bağlı olarak iklim değişikliği faaliyetlerinin farklılık göstermesidir (Erbil ve Erbil, 2019). Her iki KA'nın yalnızca organizasyon yapısı incelendiğinde bile bu farklılaşma açık bir şekilde görülmektedir. "Bulgular ve Tartışma” bölümünde detaylı olarak ele alınacağı üzere, iZKA “yeşil büyüme” ve "mavi büyüme” konseptleriyle iklim değişikliğini çalışmalarının merkezine yerleştirirken, iSTKA ise iklim ve çevre konularını öncelik verdiği alanlar arasında tanımlamamaktadır. Böylece, benzer özelliklere sahip iki KA'nın iklim değişikliği vizyonlarının farklılaşmasının, bilimpolitika arayüzü faaliyetleri üzerindeki etkisinin incelenebileceği öngörülmüştür. Yalnız bu inceleme vaka karşılaştırması olarak tasarlanmamış; iki vakadan elde edilen verilerin bilimpolitika arayüz kavramı bağlamında inceleme ve değerlendirmesi yapılacak şekilde çalışma kurgulanmıştır. 


\section{I. Vaka Çalışmasının Yöntemi}

iSTKA ve IZKA'nın incelenmesinde nitel araştırma yöntemleri olan "doküman analizi" ve "yarı yapılandırılmış görüşmeler" kullanılmıştır. Doküman analizi için, her iki KA'nın 2010-2019 yılları arasında yayınladıkları Faaliyet Raporları ve Çalışma Programları, KA'ların stratejilerini belirleyen çerçeve planlar olan 2014-2023 Bölge Planları ve resmi internet siteleri analiz edilmiştir. Yapılan bu analizde, KA'ların iklim değişikliği ile ilişkilendirilebilecek bütün faaliyetleri sistematik olarak çözümlenmiş ve gruplandırılmıştır. Bu faaliyetlerde KA'ların işbirliği gerçekleştirdiği paydaşlar belirlenerek, ilgili faaliyetlerde bilim-politika arayüzlerinden yararlanılıp yararlanılmadığı tespit edilmiştir. Bu araştırmaları derinleştirmek ve ajanslara dair arka plan bilgilerine ulaşabilmek için ise iZKA'dan beş uzman ve ISTKA'dan iki uzman ile yarı yapılandırılmış görüşmeler gerçekleştirilmiştir. Görüşmelerde, "Kuramsal Çerçeve" bölümünde paylaşılan yazın taraması esas alınarak KA uzmanlarına üç ana başlıkta sorular sorulmuştur: "Bilimsel bilgiye karşı tutum”, "bilim-politika arayüzlerine karşı tutum", "bilim-politika arayüzlerindeki zorluklar ve çözümler". Görüşmeler esnasında, KA’ların iklim değişikliği ve çevre konularıyla ilgili çalışmalarına öncelik verilmiş, ancak KA uzmanlarını bilimsel bilgi ve bilim-politika arayüzlerine dair genel perspektiflerini öğrenebilmek için KA’ların diğer alanlardaki faaliyetleri üzerinde de durulmuştur. KA'lar dört ana kriter belirlenerek sistematik bir şekilde incelenmiştir. Bu kriterler şunlardır: (i) politika oluşturma/planlama süreçlerine bilimsel bilgiyi dahil etmek, (ii) politika oluşturma/planlama süreçlerinde bilim-politika arayüzleri oluşturmak, (iii) bilim-politika arayüzlerini ortak üretime dayalı olarak tasarlamak ve (iv) bilim-politika arayüzlerini olumsuz etkileyen bariyerlerin ve bu bariyerleri aşabilmek için olası çözümlerin farkında olmak. Bir sonraki başılıta işaret edilen kriterler çerçevesinde vaka çalışmalarının bulguları ortaya koyulacaktır.

Ancak, "Bulgular ve Tartışma" bölümüne geçmeden önce, araştırmanın iki kısıdına değinilmesi yerinde olacaktır. Öncelikle, bu çalışma bir vaka çalışmasıdır ve vaka çalışmalarında incelenen örnekler daha geniş bir grubu temsil edemeyeceği için elde edilen bulgular genelleştirilemez (Maxwell, 20I3: 82-83). Bu sebeple, iSTKA ve IZKA araştırma sonuçlarının diğer KA'lar ya da politika yapıcı kurumlar için doğrudan geçerli olacağı iddia edilmemektedir. Bununla birlikte, ISTKA ve iZKA'nın bilim-politika arayüzlerini nasıl oluşturdukları ve hangi koşullar altında daha etkili sonuçlar elde ettikleri araştırılarak, konuya dair bir genel değerlendirme yapılmasının mümkün olabileceği düşünülmüştür. Bu değerlendirmede isTKA ve iZKA'nın iklim değişikliği vizyonlarının farklı olmasının sonuçları, özellikle de bu durumun bilim-politika arayüzleri faaliyetlerini nasıl etkilediği incelenmiş ancak iki kurumun iklim değişikliğine ilişkin perspektiflerinin birbirinden ayrılmasının nedenlerini doğrudan araştırmak çalışmanın kapsamı dışında bırakılmıştır. İkinci kısıt ise, araştırma bulgularının iSTKA ve iZKA doküman incelemeleri ve uzman görüşmeleri ile elde edilmesi, yani içerdiği bilgilerin kurumların perspektiflerine dair olmasıyla ilgilidir. KA'ların her bir faaliyetini münferit olarak baştan sona incelemek ya da KA uzmanlarının kendi kurumlarına karşı ne kadar objektif olduklarını ölçmeye çalışmak araştırmanın kapsamı dışındadır. Şüphesiz, bilim-politika arayüzlerinde KA uzmanlarıyla işbirliği yapan bilgi üreticiler ile yapılacak görüşmeler, meselenin başka boyutlarının keşfedilmesine imkân tanıyacaktır.

\subsection{Bulgular ve Tartışma}

\subsection{Politika Oluşturma/Planlama Süreçlerine Bilimsel Bilgiyi Dahil Etmek}

Bilimsel bilginin politika oluşturma ve planlama sürecine dahil edilebilmesi için, öncelikle karar vericilerin bilimsel bilgiye dair farkındalık sahibi olması ve bu bilginin sürecin bir parçası haline gelmesini istemesi gerekmektedir. Aslında planlama disiplini, uygulama sürecinin başlangıcını ilgili bilginin derlenmesi olarak görür ve plancı bu kabulü uygulamaya doğal olarak yansıtır. Söz konusu yansıtma plancı için artık bir refleks olarak gelişmiş ve neredeyse rutinleşmiştir. Bununla birlikte bu kriterde, politika yapıcıları temsil eden plancıların bu rutinleşmiş yaklaşım içinde, bilimsel bilgiyi ne kadar rutin dışına çıkardığı ve "bilinçli ve farkında" olarak sürece dahil ettiği sorgulanmaktadır.

ISTKA ve IZKA incelemeleri ajansların faaliyetlerini disiplinin doğal rutini içinde gerçekleştirdiklerini ve çerçeve planlar olan 2014-2023 Bölge Planlarını bilimsel bilgiye dayanarak oluşturduklarını göstermiştir (bkz. iSTKA, 2014: 46-67; iZKA, 2014: 28-49). KA'ların etkileşime girdiği bilgi üreticiler arasında ulusal veya uluslararası kamu ve özel üniversitelerden akademisyenler, il/ilçe belediyeleri, müdürlükler, bakanlıklara bağlı kurumlar, ulusal vakıflar, uluslararası organizasyonlar ve düşünce kuruluşları yer almaktadır. Bununla birlikte, "Vaka Çalışması" başlı̆ıında kısaca değinildiği ve bir sonraki kriterde detaylı olarak açıklanacağı üzere, söz konusu husus iklim değişikliğine ilişkin bilimsel bilgi olduğunda iki ajansın yaklaşımları farklılaşmaktadır. Her ne kadar enerji, ulaşım ve atık yönetimi gibi konulara dair bilgiler iklim değişikliğiyle ilişkilendirilebilse de, isTKA'nın odak noktaları arasında iklim değişikliği yer almadığı için ajans doğrudan bu konuya yönelik bir bilimsel bilgi edinme çabası içinde görünmemektedir. Buna karşılık iZKA ise iklim değişikliğine yönelik bilimsel bilgi edinmeye özel bir çaba harcamakta ve kaynak ayırmaktadır. IZKA uzmanlarının görüşmelerde vurguladığı nokta, ajansın bilimsel yöntemlere dayandığı ve güvenilir olduğu sürece her ölçekten ve kurumsal yapıdan iklim değişikliğine ilişkin bilimsel bilgi edindiğidir. Bu bağlamda, IZKA'nın başvurduğu bilgi üretici kurum yurt dışındaki bir araştırma enstitüsü olabileceği gibi İş Dünyası ve Sürdürülebilir Kalkınma Derneği gibi bir iş derneği de olabil- 
mektedir. Bir IZKA uzmanı iklim değişikliğine ilişkin bilgileri kategorize ederek, ajansın yaklaşımını şöyle ifade etmiştir:

“iklim değişikliğiyle mücadelede (iki tür bilgi var). (Birincisi) sorun tespit etmeye yönelik bilgi. Bu sorunun varlığını insanlara yaymak açısından oldukça önemli. (İkincisi ise) çözüm üreten bilgi. Bu bilgiler bazen akademide, bazen özel sektörde, bazen uluslararası kuruluşlarda olabiliyor. Onu araştırmak (önemli)”. (iZKA, 4)

KA’lar iklim değişikliği de dahil olmak üzere gerçekleştirdikleri faaliyetlerde bilimsel bilgiye özel bir önem verseler de bu bilgiyi karar alma süreçlerindeki tek ve mutlak girdi olarak görmemektedir. Görüşmelerde isTKA ve iZKA uzmanları elde ettikleri nicel bilgilerin nitel analizini yaparak bilginin bilinçli ve farkında olarak nasıl karar alma sürecine yansıtılabileceğinin geri plan değerlendirmesini yaptıklarını, hatta diğer bilgi üreticileri ile etkileşimi arttırmaya özen gösterdiklerini belirtmiştir.

KA'ların her bir faaliyetinde bilimsel bilginin etkisini ölçmek bu makalenin kapsamı dışında kalsa da, genel olarak hem iZKA'nın hem de iSTKA'nın faaliyetlerinde temel verilerin derlenmesi ve bunların politikalara dahil edilmesi rutinleşmiş yaklaşımlardır. Bilimsel bilgiye ulaşım ve arayüz oluşturmaya yönelik farkındalık ve istekleri ise hangi içerikteki bilgiye ulaştıkları ve hangi bilgi üreticilerle nasıl bir ilişki kurguladıkları noktasında belirgin hale gelmektedir. Her iki ajansın özellikle öne çıktığı noktalardan biri ise, rutinleşmiş yaklaşım içinde politikalara yansıtılan ham bilginin işlenerek kullanılabilir bilgi haline getirilmesini sağlamaktır. Bununla birlikte, iZKA'nın ve iSTKA'nın öncelik alanlarının farklılaşması iklim değişikliğine ilişkin bilimsel bilgiye dair tutumlarını da etkilemektedir. Ayrıca, KA'ların özellikle iklim değişikliğine yönelik faaliyetlerinde bu bilgileri elde edebilmek için bilgi üreticilerle nasıl bir arayüz oluşturdukları süreçte önemli bir unsurdur.

\subsubsection{Politika Oluşturma/Planlama Süreçlerinde Bilim-Politika Arayüzleri Oluşturmak}

$\mathrm{Bu}$ kriter çerçevesinde, KA'ların faaliyetlerini tasarlar ve uygularken, KA uzmanları ve bilgi üreticiler arasında kurulan ilişkileri ve ortaklıkları, yani bilim-politika arayüzleri araştırılmıştır. KA’ların dokümanlarında ve yapılan görüşmelerde sıklıkla vurgulanan bir nokta, KA’ların faaliyetlerine başlamadan önce, ilgili çalışmaya katkı sağlayabilecek paydaşları belirleyebilmek için, kapsamlı bir paydaş analizi yapıyor olmasıdır. Geniş bir yelpazeyi kapsayan bu analizler esnasında, bilgi üreticilere de büyük bir yer ayrılmaktadır. Yapılan görüşmelerde, IZKA ve isTKA uzmanları bölgedeki üniversiteler ve akademisyenler gibi bilgi üreticilerle işbirliği gerçekleştirmeyi ajansın temel işlevlerinden ve çalışma yöntemlerinden biri olarak tanımlamıştır. Bilgi üreticiler ve $\mathrm{KA}$ yetkilileri, kurulların oluşturulması, projelerin tasarlanması, danışmanlık hizmeti sağlanması ya da mali destek programlarının hazırlanması gibi çeşitli çalışmalarda işbirlikleri gerçekleştirmektedir.
Yapılan görüşmeler sonucunda ise KA'ların bilim-politika arayüzleri oluşturma sürecinde iki ayrı işlevleri olduğu tespit edilmiştir. Bunlardan birincisi, KA'ların politika/plan geliştirici bir kurum olarak, bilim-politika arayüzleri tesis etmesidir. İkinci işlevleri ise, KA’ların bölge içindeki farklı aktörler arasında işbirlikleri sağlama görev ve sorumluluğuna ilişkindir. Gerçekten de KA'lar, aracı kurumlar olarak, bölge içinden veya dışından kamu kurumları, özel sektör birimleri, üniversiteler ve sivil toplum kuruluşları gibi çeşitli aktörleri bir araya getirdikleri faaliyetler düzenlemektedir. KA'lar oluşturdukları bu arayüzlerle, farklı ölçekler arasında köprü görevi de görmektedir. Bu bağlamda, ISTKA ve IZKA, uluslararası seviyede üretilen bilgiyi bölgesel ve yerel ölçekte eyleme dönüştürebilmek için, Birleşmiş Milletler Kalkınma Programı, Dünya Bankası, Dünya Doğayı Koruma Vakfı (World Wide Fund for Nature) veya İngiltere'deki Sanat ve Beşeri Bilimler Araştırma Konseyi (Arts and Humanities Research Council) gibi uluslararası aktörler ile bölgesel ve yerel aktörleri bir araya getiren faaliyetler yürütmektedir.

Araştırma bulguları göstermektedir ki, ISTKA ve IZKA, bilgi temelli çalışma yaklaşımları ve farklı aktörler arasında etkileşimi güçlendirme misyonları gereği, bilim-politika arayüzlerine dair yüksek bir farkındalığa sahiptir ve faaliyetlerinde bu arayüzlerden düzenli olarak yararlanmaktadır. Ancak, bu makalenin esas konusu iklim değişikliği odaklı politika üretim/planlama süreçlerindeki bilim-politika arayüzleri olduğu için, bu arayüzlere dair araştırma sonuçlarını ayrıca tartışmak gereklidir. Bu bağlamda vurgulanması gereken nokta, bilim-politika arayüzlerine dair genel perspektifleri benzer olan ISTKA ve iZKA'nın iklim değişikliğine dair tamamıyla farklı bakış açılarına sahip olmasıdır. IZKA, "sürdürülebilir kalkınma" konsepti çerçevesinde, iklim değişikliğini faaliyetlerinin merkezine yerleştirmektedir. Öyle ki, "yeşil büyüme" ve "mavi büyüme" temalarını esas alarak organizasyon yapısını da buna uygun olarak dönüştürmüştür (IZKA, 2020a). iZKA'nın iklim değişikliğine ilişkin bu genel vizyonu, ajansın sanayileşme, çevre koruma, tarımsal üretim gibi bölge planı içinde yer alan her faaliyet alanını etkilemektedir. Başka bir ifadeyle, IZKA farklı alanlardaki çalışmalarına da iklim değişikliği vizyonunu entegre etmektedir. Bir iZKA uzmanı bu entegrasyonu şöyle ifade etmektedir:

"Sürdürülebilirlik bizim temel kavramlarımızdan, çalışmalarımıza yön veren konulardan bir tanesi [...] Bu yılki organizasyon yapısının değişiminde de, mesela yeşil büyüme ve mavi büyüme gibi birimlerin kurulmasında da, bizim bu yaklaşımımız ön plana çıktı”. (IZKA 3)

Buna karşılık, bir isTKA uzmanının belirttiği gibi, iSTKA "Yenilikçilik", "Yaratıcı Endüstriler”, "Girişimcilik" ve "Çocuklar ve Gençler" gibi alanlara öncelik vermekte (ISTKA, 2019), iklim değişikliğini ancak diğer faaliyet alanları ile ke- 
Tablo I. IZKA ve ISTKA birimleri

\begin{tabular}{ll}
\hline iZKA birimleri & iSTKA birimleri \\
\hline I. Yenilik ve Girişimcilik Politikaları Birimi & I. Planlama Programlama ve Koordinasyon Birimi \\
2. Yeşil Büyüme Politikaları Birimi & 2. Program Yönetim Birimi \\
3. Mavi Büyüme Politikaları Birimi & 3. İzleme ve Değerlendirme Birimi \\
4. Proje Uygulama ve İzleme Birimi & 4. Yatırım Destek Ofisi \\
5. Yatırım Destek Ofisi & 5. Destek Birimi
\end{tabular}

IZKA: İzmir Kalkınma Ajansı; isTKA: İstanbul Kalkınma Ajansı.

siştiği durumlarda, ortak yarar olarak çalışmalarına dahil etmektedir:

"Şu an ajansın gündemi özellikle "yaratıcı endüstriler”, "girişimcilik", "inovasyon" ve "çocuklar ve gençler" konusu. "Sürdürülebilirlik”, "çevre”, "enerji” ve "ulaşım” gibi konular bu konuların ve çerçevelerin içerisinde ele alınıyor [...] Daha kapsamlı bir konu olarak görülmüyor ama bunlar içerisinde ortaya çıkabilecek proje konularından, faaliyet konularından bir tanesi olarak görülüyor”. (ISTKA I)

Tablo I'de paylaşıldığı gibi, isTKA ve iZKA'nın iklim değişikliğine vizyonlarında yer verme biçimi nedeniyle hem organizasyon şemalarında hem de iklim değişikliğine yönelik politika ve faaliyet geliştirmelerinde farklılıklar ortaya çıkmaktadır (Tablo I).

Bunun yanında, iklim değişikliğiyle mücadelede ölçeklerden bağımsız olarak farklı kurumların desteğini almanın bir zorunluluk olduğunu ifade eden IZKA uzmanları, ajansın iklim değişikliğine ilişkin faaliyetlerinde birçok farklı bilim-politika arayüzünden yararlandığını ortaya koymuştur:

"[iklim değişikliği konusunda] aktör dağılımına baktığımız zaman, tüm aktörler (ile işbirliği halindeyiz). Mesela Ege Bölgesi Sanayi Odası'nın, özellikle sanayide çevresel sürdürülebilirlik anlamında birtakım çalışmaları olan bir Çevre Çalışma Grubu var. Biz onun aktif üyesiyiz. II, Çevre ve Şehircilik Müdürlüğü, tarım ve sürdürülebilirlik konusunda faaliyet gösteren Tarım Müdürlüğü, çeşitli dernekler, üniversiteler, üniversite hocalarımız, kooperatifler iklim değişikliği konusunda temel aktörler. Ayrıca Dünya Bankası veya WWF gibi birçok uluslararası kuruluşlar ya da bu konuda çalışan diğer ajanslar bizim paydaşlarımız oluyor”. (iZKA 3)

Görüşme bulgularına ek olarak, her iki kurumun iklim değişikliğine yönelik bilim-politika arayüzleri faaliyetlerine dair bazı örnekler vermek bu bulguların somutlaştırılmasına yardımcı olacaktır. IZKA, 20I4-2023 Bölge Planı hazırlanması sürecinde iklim değişikliğine ilişkin birçok bilim-politika ara- yüzünden yararlanmıştır. Örneğin, "Urla-Çeşme Karaburun Yarımadası Sürdürülebilir Kalkınma Stratejisi” kapsamında İzmir Yüksek Teknoloji Enstitüsü, Dokuz Eylül Üniversitesi ve Ege Üniversitesi'nden on üç farklı akademisyenin işbirliği ile çok boyutlu bir bilim-politika arayüzü oluşturulmuştur. Ayrıca, “İzmir Su Ürünleri Sektörü Stratejisi” ve “İzmir'de Temiz Üretim (Ekoverimlilik) Uygulamalarının Yaygınlaştırılması Strateji Çalışması" gibi faaliyetlerde İzmir Katip Çelebi Üniversitesi, TTGV ve Orta Doğu Teknik Üniversitesi (ODTÜ) gibi bilgi üretici kuruluşlardan temsilcilerle ortak çalışmalar gerçekleştirilmiştir (IZKA, 20।4: 208-2।0). IZKA sonraki süreçte TTGV ile oluşturduğu bilim-politika arayüzünü devam ettirerek İzmir'deki sanayi kuruluşlarının kaynak tüketimini çevreye daha duyarlı hale getirmek için "İzmir Eko-verimlilik (Temiz Üretim) Programı”nı hayata geçirmiştir. Bu program çerçevesinde, bölgede eğitim ve uygulama çalışmaları gerçekleştirilmiş ve kaynak kullanımı ve kirliliğin azaltılmasına yönelik önemli kazanımlar elde edilmiştir. IZKA verilerine göre, bu program sayesinde, 125,8 ton/yıl tuz kullanımı azaltması, 7,285 ton/yıl karbondioksit salımı azaltması, $27,049 \mathrm{~m}^{3} / \mathrm{yıl}$ atık su miktarı azaltması, 321 ton/yıl katı atık miktarı azaltması, 57,6 ton/yıl kimyasal tasarrufu, 7I,049 m³ yıl su tasarrufu, 837,8 TEP/yıl enerji tasarrufu ve 100 ton hammadde tasarrufu sağlanmıştır (IZKA, 202I). Bölgeye ilişkin bilimsel bilgileri temel alarak uygulanan ve sonrasında çıktıları takip edilen bu program sayesinde, İzmir bölgesinde, iklim değişikliğine dolaylı ve doğrudan etki eden bazı kaynak kullanımı ve atıkların sistemden çıkarılması mümkün kılınmıştır. Böylece iklim değişikliğine sebep olan sera gazları salımını azaltacak ve iklim değişikliği nedeniyle oluşacak yeni koşullara uyum sağlamayı kolaylaştıracak çıktılar elde edilmiştir. IZKA'nın daha güncel bir faaliyeti ise Sanayi ve Teknoloji Bakanlığı Kalkınma Ajansları Genel Müdürlüğü tarafından koordine edilen ve Çevre ve Şehircilik Bakanlığı ve Bursa Eskişehir Bilecik Kalkınma Ajansı ile ortaklık gerçekleştirdiği "endüstriyel simbiyoz” projesidir (IZKA, 20I9). IZKA, bölgedeki aktörlerin birbirleriyle atık, yan ürün, enerji ve insan kaynaklarını paylaşabileceği endüstriyel simbiyoz dönüşümünü hayata geçirebilecek bir yol haritası oluşturulması adına, BM Kalkınma Programı gibi uluslararası partnerlerle de işbirliği yaparak bölgedeki paydaşlarla fikir alışverişi ger- 
Tablo 2. IZKA'nın iklim değişikliğine ilişkin faaliyetlerine bazı örnekler

\begin{tabular}{|c|c|}
\hline \multicolumn{2}{|c|}{ IZKA } \\
\hline Proje/toplantı/etkinlik & İşbirliği gerçekleştirilen kurum \\
\hline $\begin{array}{l}\text { Türkiye Endüstriyel Simbiyoz Yol Haritasının Geliştirilmesi Projesi } \\
\text { (devam ediyor) }\end{array}$ & $\begin{array}{l}\text { Çevre ve Şehircilik Bakanlığı ve Bursa Eskişehir Bilecik Kalkınma } \\
\text { Ajansı }\end{array}$ \\
\hline İzmir Eko-Verimlilik (Temiz Üretim) Programı & Türkiye Teknoloji Geliştirme Vakfı \\
\hline $\begin{array}{l}\text { Türkiye İçin Yeşil Organize Sanayi Bölgesi (OSB) Çerçevesinin Ge- } \\
\text { liştirilmesi Projesi (2019) }\end{array}$ & Dünya Bankası \\
\hline $\begin{array}{l}\text { Yeşil Teknolojilerde Startup ve Kurumsal Şirket Buluşma Programı- } \\
\text { GreenTech İzmir (2018) }\end{array}$ & Türkiye Ekonomi Politikaları Araştırma Vakfı \\
\hline Eko-Endüstriyel Park ve Yeşil OSB Geliştirme Faaliyetleri (2018) & İzmir Atatürk Organize Sanayi Bölgesi (IAOSB) \\
\hline Çevresel Ayak İzi ve Ekoetiket Çalışmaları (2017) & $\begin{array}{l}\text { Ege Orman Vakfı ve Hayat Boyu Öğrenme, Mesleki Eğitim ve Ge- } \\
\text { liştirme Derneği }\end{array}$ \\
\hline İklim Değişikliği, Sürdürülebilir Tarım, Kırsal Kalkınma (20I7) & Dünya Bankası \\
\hline Yarımada Sürdürülebilir Kalkınma Stratejisi (20|4) & $\begin{array}{l}\text { İzmir Yüksek Teknoloji Enstitüsü, Ege Üniversitesi ve Dokuz Eylül } \\
\text { Üniversitesi }\end{array}$ \\
\hline
\end{tabular}

IZKA: İzmir Kalkınma Ajansı.

Tablo 3. ISTKA'nın iklim değişikliğine ilişkin faaliyetlerine bazı örnekler

\begin{tabular}{|c|c|}
\hline \multicolumn{2}{|c|}{ ISTKA } \\
\hline Proje/toplantı/etkinlik & İşbirliği gerçekleştirilen kurum \\
\hline İstanbul İklim Değişikliği Çalıştayı (20।7) & İstanbul Büyükşehir Belediyesi \\
\hline Yaşanabilir Şehirler Sempozyumu (2017) & $\begin{array}{l}\text { World Resources Institute Türkiye ve Hollanda İstanbul Başkon- } \\
\text { solosluğu }\end{array}$ \\
\hline Hello Tomorrow: Future of Energy (2016) & Sabancı Üniversitesi \\
\hline Ortak Akıllar: Alman Türk Genç Uzmanlar Girişimi (20I5) & $\begin{array}{l}\text { Robert Bosch Vakfı, Berlin Avrupa Akademisi ve Sabancı Üniversite- } \\
\text { si İstanbul Politikalar Merkezi (IPM) }\end{array}$ \\
\hline $\begin{array}{l}\text { Ömerli Havzası'nda Ekosistem Servislerine Dayalı Havza Yönetim } \\
\text { Planı'nın Geliştirilmesi (20I5) }\end{array}$ & ITÜ Mimarlık Fakültesi \\
\hline Sürdürülebilir Ulaşım İçin Türkiye AB Ortaklığı Semineri (20।5) & Ulaştırma, Denizcilik ve Haberleşme Bakanlığı \\
\hline $\begin{array}{l}\text { Türkiye'de İnşa Edilecek Nükleer Santrallerde Yerli Katkı Oranının } \\
\text { Artırılması Projesi (20।4) }\end{array}$ & ITÜ Enerji Enstitüsü ve Enerji ve Tabii Kaynaklar Bakanlığı \\
\hline $\begin{array}{l}\text { Metrobüslerde Akıllı Ulaşım Sistemleri Uygulanması ile Verimlilik } \\
\text { Artışı Fizibilite Çalışması (20I3) }\end{array}$ & Okan Üniversitesi \\
\hline
\end{tabular}

isTKA: İstanbul Kalkınma Ajansı.

çekleştirilen çalıştaylar ve eğitimler düzenlemektedir (IZKA, 2019, 2020b) (Tablo 2). ISTKA da Bölge Planı hazırlık sürecinde "Sürdürülebilir Kaynak ve Atık Yönetimi" tematik toplantısıyla Boğaziçi Üniversitesi, İstanbul Teknik Üniversitesi, TEMA Vakfı gibi bilgi üreticiler ile çeşitli kamu kurumlarının bir araya geldiği bir bilim-politika arayüzü oluşturmuştur (ISTKA, 20।4: 516-5I7). ISTKA'nın iklim değişikliğine yönelik başka bir ortaklık çalışması ise, İstanbul Büyükşehir Bele- diyesi İstanbul İklim Değişikliği Eylem Planı projesine katılım göstermektir (ISTKA, 2019: 30) (Tablo 3).

Her ne kadar yukarıdaki örnekler konuya dair fikir vermesi için seçilmiş birkaç örnek olsa da, genel olarak, iZKA'nın doğrudan iklim değişikliğine odaklanan ve bölge için elle tutulur ve dönüştürücü faaliyetler gerçekleştiren bilim-politika arayüzleri oluşturduğu, ISTKA'nın ise son yıllarda iklim değişikliğine 
yönelik doğrudan ve aktif çalışmaları gerçekleştirmediği ve dolayısıyla bu konuya yönelik bilim-politika arayüzleri oluşturmadığı görülmektedir.

\subsubsection{Bilim-Politika Arayüzlerini Ortak Üretime Dayalı Olarak Tasarlamak}

iSTKA ve iZKA'nın bilim-politika arayüzü faaliyetlerine ek olarak, "ortak üretim" temelli bilim-politika arayüzü perspektifine sahip olup olmadığı da önemlidir. Aslında KA’ların kuruluş sebepleri ve amaçları gereğince, belirli vizyonlar çerçevesinde uzun soluklu yol haritaları oluşturması ve geliştirecekleri projeler, planlar ve politikalar veya diğer paydaşlarla kuracakları ortaklıklar gibi faaliyetlerini bu yol haritalarına bağı olarak sürdürmesi beklenmektedir (T.C. Cumhurbaşkanlığı, 2018). Örneğin, her KA'nın kendi bölgesi için bir çerçeve plan olarak hazırladığı 20।4-2023 Bölge Planları ya da belirledikleri Sonuç Odaklı Programlar, bölgeye dair yürütülecek çalışmalar için üst ölçekli rehberler niteliği taşımaktadır. Ancak, KA’ların bu çalışma yöntemi, vizyonlarını ve politikalarını tek başlarına belirledikleri ve farklı görüşlerden yararlanmadıkları anlamına gelmemelidir. Aksine, iSTKA ve IZKA uzmanlarının ısrarla üzerinde durduğu üzere, KA'lar stratejik planlarını belirlerken ilk aşamadan itibaren toplumun farklı kesimlerinin görüşlerini almaya özen göstermektedir. ISTKA ve IZKA'nın hazırladığı Bölge Planları da, ilgili planların hazırlık sürecinde, bölge içindeki veya dışındaki, kamu kurumları, üniversiteler, araştırma enstitüleri, teknoparklar, özel şirketler, meslek odaları, sivil toplum kuruluşları gibi farklı birimlerden, oldukça fazla sayıda aktörün katkı sağladığını göstermektedir (bkz. ISTKA, 20।4: 5।4-524; iZKA, 2014: 207-240).

Bu bulgulardan hareketle, isTKA ve iZKA'nın katılımcı bir yöntem izlemeye ve politikalarını/planlarını farklı paydaşların görüşleriyle "birlikte üretmeye" gayret gösterdikleri belirtilebilir. Yukarıda da bahsedildiği üzere, faaliyetlerinde bilimsel bilgiye özel bir değer atfeden KA'lar için bilgi üreticiler, bu paydaşlar arasında önemli bir yer tutmaktadır. Bir önceki kriterde açıklanan IZKA'nın “İzmir Eko-verimlilik (Temiz Üretim) Programı” ortak üretim bağlamında iyi bir örnek olarak değerlendirilebilir. Bir IZKA uzmanı tarafından "en kritik, dışarıda etkilerini görebileceğimiz strateji" olarak tanımlanan Eko-verimlilik Programı'nın tasarlanması, uygulanması ve yaygınlaştırılması sürecinin IZKA ve TTGV'nin karşılıklı deneyim ve bilgi paylaşımı ile gerçekleştiğinin altı çizilmiş ve ODTÜ'den ve İzmir'den akademisyenlerin de projeye katkı sağladığı belirtilmiştir (IZKA ve TTGV, t.y.). Böylece, bu program kapsamında, farklı bölgelerden, kurumlardan ve uzmanlıklardan bilgi üreticileri bir araya getiren bir bilim-politika arayüzü oluşturulmuştur. IZKA'nın tek başına inisiyatif almadığı, bilgi ve aksiyonun birlikte üretildiği bu program, ortak üretim modeliyle önemli ölçüde uyuşmaktadır.
Bununla beraber, iklim değişikliğine ilişkin kavramların bölgede yaygınlaştırılması gerektiğinde, bölgede halihazırda bir talep yoksa IZKA'nın “ortak üretim modeli”nden görece uzaklaşarak daha baskın bir rol oynadığı bir IZKA uzmanı tarafından belirtilmiştir:

"[Diğer kurumlardan gelen katkılar da politikaları ve projeleri] bazı konularda şekillendiriyor bazı konulardaysa biz ısrarla o konunun çok önemli olduğunu görüp o konuda ısrar edebiliyoruz. [...] Yönlendirme ve yaygınlaştırma bence kalkınma ajanslarının Türkiye'ye en büyük etkilerinden. Mesela uluslararası kalkınma gündeminin yerele taşınması, iklim değişikliği, sürdürülebilirlik, ekoverimlilik, dijitalleşme, endüstri 4.0... Bunların gündeme taşınmasını, bazı desteklerle, toplantılarla, yönlendirmeye ve yaygınlaştırılmaya çalışılmasını da yapıyoruz”. (IZKA, 4)

Bununla birlikte, aynı IZKA uzmanının, ajansın bilgi üreticilerle ilişkisinin nasıl olması gerektiğine dair yorumunun, ortak üretim temelli bilim-politika arayüzü modeliyle örtüştüğü görülmektedir:

"O insanlarla [bilgi üreticilerle] bir hizmet alımı bakış açısıyla değil de, aynı masada birlikte oturup birlikte çalışan paydaşlar olduğunuz hissiyle çalışmanız gerekiyor. Siz konuya ekip olarak bakmıyorsanız, o çalışma bir yerde kalıyor. Hizmet alımı mantı̆̆ından birlikte çalışma mantığına gitmemiz lazım”. (iZKA 4)

Sonuç olarak, her ne kadar uzun vadeli planları ve programları KA'ların faaliyet alanlarına ilişkin genel bir sınır çizse de iSTKA ve IZKA'nın bilgi üreticilerle ortak faaliyetlerinde ne tamamen egemen rolü üstlendikleri ne de pasif kaldıkları öne sürülebilir. Özellikle iZKA'nın iklim değişikliği faaliyetlerindeki bu yaklaşımı, ortak üretim modeliyle kayda değer benzerlikler göstermektedir.

\subsubsection{Bilim-Politika Arayüzlerini Olumsuz Etkileyen Bariyerlerin ve Bu Bariyerleri Aşabilmek Iç̧in Olası Çözümlerin Farkında Olmak}

Dinamik bir yapıya sahip olan bilim-politika arayüzlerinin oluşturulması ve sonrasında etkin bir şekilde sürdürülebilmesi için bilgi üreticiler ve politika yapıcılar arasındaki mevcut ve olası bariyerlerin bilincinde olmak kritik öneme sahiptir. Bu noktadan hareketle bu kriter ile, isTKA ve IZKA uzmanlarının bilim-politika arayüzlerinde karşılaştıkları bariyerlere ve bu bariyerleri aşmaya yönelik çözüm önerilerine dair farkındalık seviyeleri araştırılmıştır. KA uzmanlarının geçmiş arayüz deneyimlerine ve konuya dair çıkarımlarına dayanan bu bulgular, genel olarak bilim-politika arayüzlerinde karşılaşılan veya karşılaşılması beklenen sorunlara ilişkindir. Ancak, özel olarak bu makalenin odak noktası olan iklim değişikliğine yönelik bilimpolitika arayüzlerini de kapsamaktadır. 
Öncelikle, ilgili literatürde sıklıkla iki grup arasındaki temel bariyerler olarak vurgulanan, "bilgi üreticiler ve politika yapıcıların farklı dünya görüşlerine sahip olmasının” ve "bilimsel belirsizliklerin” iSTKA ve IZKA yetkilileri için bir engel teşkil etmediği tespit edilmiştir. Bu durumun esas sebebi, KA uzmanlarının çoğunlukla akademik olarak yüksek eğitim almış olması, yani bilim dünyasıyla ve bilgi üreticilerle, ortalama bir kamu personeline kıyasla, daha nitelikli ve etkin ilişkiler kurabilmeleridir. KA uzmanlarının bu özelliği nedeniyle, ilgili literatürde, bilim dünyası ve politika dünyası arasındaki etkileşimi geliştirebilmek için önerilen arabulucu kurum ve kişiler de, ISTKA ve iZKA örneklerinde gerekli bir çözüm önerisi olarak değerlendirilmemiştir. Arabulucu rolünü doğal olarak kurum yetkilileri üstlenmektedir.

Bununla beraber, KA uzmanlarının bilim okuryazarlığının yüksek olması, iki grup arasındaki bariyerleri tamamen ortadan kaldırmamaktadır. KA uzmanları, kendi kurumları ve bilgi üreticilerin çalıştıkları kurumların farklı hedeflere yönelik çalışmasının bilim-politika arayüzlerinin oluşturulmasını güçleştirdiğini ifade etmiştir. Örneğin, bir iZKA uzmanına göre, akademinin öncelikleri her zaman işbirlikleri kurmaya uygun değildir:

"Akademinin hem sivil toplum örgütleri hem özel sektörle bağları burada zayıf. [...] Akademi hâlâ kendi rolünü bilgi üretmek, toplumun ihtiyacı olan insan kaynağını yetiştirmek ve bunun ötesine çıkmamak olarak tanımlıyor. Dolayısıyla, kendi öğrencilerinde, kendi grubunda bir gönüllülük, toplum hayatına etki eden unsurlara müdahale etme, doğrudan onların kendi hayatına dahil etme ve içselleştirme anlamında güçlü bir yaklaşım sürdüremiyor”. (IZKA I)

Bir iSTKA uzmanı ise kurumlar ve kişiler arasında idealler ve ideolojilerin farklılaşmasının bir bariyer olarak görülebileceğine dikkat çekmiştir:

“Bence Türkiye'de perspektif farklılıkları çok şeyi engeller nitelikte. [...] Sosyalizmin çıkış olduğunu düşünen bir akademisyeni özel sektör sorunlarını çözmesi için çalıştırmak bence kolay olmaz [...] iSTKA'da bizim yaşadığımız problemler böyle şeylerden etkileniyordur, biz farkında olsak da olmasak da. Birebir böyle bir şey deneyimlediğim için söylemiyorum ama kuruma uzak duran akademisyenler olabilir veya ajansın duruşu (bazı) uzman ve çok iyi akademisyenlere belki daha uzak gelebilir. Bir şekilde zaten ortak bir noktada hiç buluşamıyor olabiliriz. Yani bunun hiç farkında olmayabiliriz". (ISTKA 2)

$\mathrm{Bu}$ bariyerlere ek olarak, bürokratik süreçlerin uzun sürmesi, özellikle birden fazla kurumdan bilgi üreticinin dahil olduğu arayüzlerin finansal yönetiminin güçleşmesi ve her grubun kendi sorumluluklarından dolayı ortaklıklara yeterince zaman ayıramaması gibi bariyerler de görüşmelerde dile getirilmiştir. Ana hatlarıyla genel nitelikli olan bu bariyerlere ilişkin ISTKA ve
IZKA uzmanlarının bazı çözüm önerileri de bulunmaktadır. Öncelikle, her iki KA uzmanları, bilgi üreticiler ile düzenli toplantılar gerçekleştirmenin, bölgelerindeki bilimsel faaliyetlere dair fikir sahibi olmalarını sağlayacağını ve karşılıklı ilişkileri geliştirerek bariyerlerin aşılmasında önemli bir adım olacağını belirtmişlerdir. Ayrıca, uzmanlar, bilgi üreticilerin misyonlarını bölgeye dair somut problemlerin çözümü için ortaklıklar kurmaya daha çok önem verecek şekilde tekrar tanımlamaları gerektiğini ifade etmiştir. Bir IZKA uzmanı bu noktayı şöyle özetlemektedir:

“Zaman zaman Avrupa'ya gittiğimizde gördügümüz şey (şu); [...] bölgesel meselelerle üniversitelerin çalıştığı meseleler belirli bir oranda örtüşüyor. Bu örtüşmelerden de ister istemez daha fazla işbirliği alanı doğmuş oluyor [...] Belki zaman içinde bahsettiğim bölgesel konularla üniversitelerin çalıştığı alanların örtüşmesi biraz daha ayakları yere basan, biraz daha yerelde temeli olan, yerele fayda sağlayacak, daha kolay işbirliklerine sahne olabilecek konuları öne çıkarabilir diye düşünüyorum [...] Bunu daha ileriye götürmek için, bir üniversite bir bölgedeyse, mesela lzmir'de bir üniversite ise Izmir'in meselesi ne (buna bakması lazım). İklim değişikliği bunlardan bir tanesi..." (IZKA 2)

KA uzmanları ile yapılan görüşmeler, bölgelerinin karakteristiklerinin de bilgi üreticilerle ortaklık kurmalarını etkilediğini ortaya koymuştur. Bu makale kapsamında, KA'ların sorumlu oldukları bölgelerin coğrafi ve demografik niteliklerini ifade eden “ölçek faktörü”, en önemli bölgesel özellik olarak tespit edilmiştir. Her ne kadar hem İzmir hem de İstanbul metropol şehirler olsalar da, ölçek faktörü göz önüne alındığında, iZKA'nın sorumlu olduğu İzmir bölgesi, bir yandan yeterli miktarda insan kapasitesi ve üniversitelere sahip olması, diğer yandan ise İstanbul gibi devasa bir metropol olmaması ile ortak üretim dahilinde politika geliştirilmesi için optimum ölçeğe yakındır. iSTKA'nın ise, nüfusu 15 milyonu aşan ve bünyesinde oldukça fazla sayıda üniversite, araştırma merkezi ya da diğer bilgi üretici kuruluşa sahip olan İstanbul'un devasa ölçeği içinde bilim-politika arayüzleri oluşturması hayli güçtür. Bu güçlüğün temel sebebi, herhangi bir faaliyeti gerçekleştirmek için ilgili bütün paydaşları tespit edecek bir analiz yapmanın ve bu analiz ile belirlenen paydaşlar arasında tercihte bulunmanın, hatırı sayılır derecede vakit alan, yüksek maliyetli ve kimi zaman ortaklık kurulmayan paydaşlarla ilişkilerin bozulması neticesini veren bir süreç olmasıdır. İzmir ve İstanbul bölgeleri arasındaki bölgeye özgü bir diğer fark ise merkezi hükümet, uluslararası kuruluşlar ya da büyük şirketler gibi güçlü aktörlerin ilgi odağı olan İstanbul bölgesinde, bilimpolitika arayüzleri tesis etmek de dahil olmak üzere, herhangi bir bağımsız faaliyet yürütmenin, İzmir bölgesine kıyasla daha zor olduğu gerçeğidir.

Sonuç olarak, bilim-politika arayüzlerini olumsuz etkileyen bariyerlerin ve bu bariyerleri aşabilmek için olası çözümlerin farkında olmak bağlamında, KA uzmanlarının hem genel nitelikli 
hem de bölgelerine özgü bariyerlere dair detaylı açıklamalarda bulundukları görülmektedir. Üstelik uzmanların, her ne kadar bölgelere özgü bariyerler kısa vadede çözüme ulaştırılacak sorunlar gibi görünmese de, genel nitelikli bariyerlere ilişkin çözüm önerileri geliştirmeye istekli oldukları da ifade edilebilir. KA uzmanları tarafından bu bariyerlerin tespit edilmiş olması, bilim-politika arayüzlerinin kurulmasına dair cesaret kırıcı bir durum olarak görülmemelidir. Aksine, bariyerlere ilişkin farkındalık sahibi olmanın, işlevsel bilim-politika arayüzleri tesis edilmesi yolunda çözüm önerileri geliştirilmesinin ilk adımı olarak değerlendirilmesi daha doğru olacaktır.

\section{Sonuç}

Çağımızın en büyük tehditlerinden biri olan iklim değişikliğinin etkilerini azaltmaya ya da kaçınılmaz sonuçlarına uyum sağlamaya yardımcı olacak politikaların bilimsel bilgi olmadan üretilemeyeceği gerçeği, bilim dünyası ve politika dünyası arasında güçlü ve sürdürülebilir bir işbirliğini zorunlu kılmaktadır. İşaret edilen noktadan hareketle, bu makalede, iklim değişikliğine ilişkin bilimsel bilginin etkin politikalara dönüştürülebilmesi için, bilgi üreticiler ve politika üreticilerin/plancıların birlikte bilgi, politika ve eylem üretebilecekleri ortak üretime dayalı bilim-politika arayüzlerinin oluşturulması gerektiği iddia edilmiştir. Makalenin "ortak üretim” yaklaşımı, bilimsel bilgiyi kutsallaştıran bilimperest (scientism) ya da politika yapıcı/plancıyı mutlak karar verici olarak gören geleneksel görüşe alternatif olarak tanıtılmıştır.

Bu noktadan hareketle, bilim-politika arayüzlerinin pratik boyutlarını araştırabilmek için, ISTKA ve IZKA vaka çalışması olarak ele alınmış ve üç ana noktaya vurgu yapılması gerektiği saptanmıştır. Bunlardan ilk ikisi etkin iklim politikası geliştirmesinde faydalı görülen saptamalar iken, sonuncusu ortak üretim temelli bilim-politika arayüzünün sağlıklı kurulması ve sürdürülmesine yöneliktir. Birinci saptama, yerel ve bölgesel politikaların geliştirilmesinde iklim değişikliğinin temel vizyon olarak belirlenmesinin önemli bir fark yaratmasına ilişkindir. Araştırmada ISTKA ve IZKA'nın genelde bilim-politika arayüzlerine yaklaşımlarının birbirine çok benzer olduğu tespit edilmiştir. Ancak iki KA'nın faaliyetleri içinde iklim değişikliği konusunun nerede ve hangi çerçevede ele alındığı farklılık göstermektedir. IZKA iklim değişikliğini ve sürdürülebilirliği çalışmalarının merkezine koymakta ve hemen hemen bütün faaliyetlerini iklim değişikliği odaklı bir vizyon çerçevesinde sürdürmektedir. ISTKA ise iklim değişikliğini öncelikli faaliyet alanları arasında tanımlamamakta ve yenilikçilik, yaratıcı endüstriler, girişimcilik, ve çocuklar-gençler gibi alanlara öncelik verip iklim değişikliğine dair faaliyetleri bu konular üzerinden bir "ortak yarar" sağlayacak şekilde konumlandırmaktadır. Bu vizyon farklılığı sonucu, IZKA'nın iklim değişikliğine ilişkin bilim-politika arayüzlerinin isTKA'ya kıyasla daha fazla sayıda, daha etkin ve sürdürülebilir olduğu görülmektedir. Başka bir ifadeyle, iklim değişikliği söz konusu olduğunda, kurumların vizyonlarının doğrudan ve öncelikle iklim değişikliğine yönelik şekillendirilmesi, bilim-politika arayüzlerinin niteliğini ve dolayısıyla iklim değişikliğine ilişkin politika/planlarını da etkilemektedir. Söz konusu iklim değişikliği vizyonunun önemini, İzmir kenti yerel yönetiminin en önemli temsilcisi olarak İzmir Büyükşehir Belediye Başkanı Tunç Soyer de Nisan 202l'de gerçekleştirilen Türkiye Belediyeler Birliği 5. Toplantısı'nda net bir biçimde ifade etmiştir. Soyer konuşmasında, ulaşım, tarım, sanayi, turizm, su yönetimi ve enerji gibi politikanın bütün alanlarının "iklim kriziyle mücadele" ana başlığı altında ele alınmasının gerekli olduğunu vurgulamıştır (Soyer, 202I).

İkinci saptama birinciyle doğrudan bağlantılı olmakla birlikte ayrı bir başlık olarak ele alınmayı gerektirmektedir. Bu saptama, iklim değişikliğine yönelik "ortak yarar” anlayışının etkin politikalar geliştirilmesinde yetersiz kalmasıdır. Biraz önce ifade edildiği gibi İSTKA iklim değişikliğini yenilikçilik, girişimcilik ve yaratıcı endüstriler gibi öncelik alanlarına bir "ortak yarar" olarak dahil etmektedir. Dolayısıyla, ISTKA iklim değişikliğine yönelik doğrudan bir faaliyet tasarlamamakta, iSTKA'nın iklim değişikliğine ilişkin bir faaliyet geliştirilebilmesi için bu faaliyetin ajansın öncelik alanlarından birinin alt başlığı olarak değerlendirilebilmesi gerekmektedir. ISTKA'nın yaklaşımı, iklim değişikliği gibi acil sistemsel dönüşüm gerektiren bir alan için pasif değilse bile etkinliği az bir yöntem olarak karşımıza çıkmaktadır. İklim değişikliği yalnızca bir "ortak yarar” olarak ele alındığında konuya ilişkin hem bilim-politika arayüzlerinin etkinliğinin sınırlı kaldığı hem de sahada faaliyet yaratan politikalar üretilemediği gözlemlenmektedir. Bu doğrultuda, bir önceki saptamayla da bağlantılı olarak, KA'ların bölgesel düzeyde iklim değişikliği faaliyetleri yürütmeyi öncelikleri olarak tanımlamalarına ve bölgelerindeki paydaşlar arasında bu konuya doğrudan ilişkin farkındalığı ve işbirliğini artırmaya yönelik çalışmalarına ihtiyaç vardır. Her ne kadar merkezi hükümete bağlı kurumlar olarak ulusal planlardan tamamen bağımsız hareket edemiyor olsalar da, KA'ların -IZKA örneğinde görüldüğü gibi- işaret edilen faaliyetler ile bölgesel düzeyde bir fark yaratmaları mümkündür. KA'ların iklim krizine ilişkin tutumları, gelecekte bu krizin Türkiye kent ve bölgelerinde doğuracağı sonuçları ve geliştirilecek çözüm önerilerini belirleyen faktörler arasında yer almaktadır.

Üçüncü saptama ise bilim-politika arayüzlerinin oluşturulmasını olumsuz etkileyebilecek ya da tamamen engelleyebilecek bariyerlerin tartışılmasının önemidir. Bu bariyerlere dair farkındalık sahibi olmak bilgi üreticilerin ve politika yapıcıların arayüzleri bilinçli bir şekilde kurmalarına ve gerektiğinde bariyerleri aşmaya yönelik çözümler üretebilmelerine yardımcı olabilecektir. Makalede ele alınan bariyerler, bilim dünyası ve politika dünyası arasındaki perspektif farklılıkları, bilimsel belirsizlikler, zaman kısıtlamaları ya da finansal sorunlar gibi genel nitelikli ya da "ölçek faktörü" gibi bölgesel nitelikli olabilmektedir. Bununla birlikte, bariyerlerin tespit edilmesi bir olum- 
suzluk olarak değil, aksine çözüm önerileri geliştirmede ilk adım olarak görülmelidir. KA'ların, diğer politika yapıcı/plancı kurumların/kişilerin ve bilgi üreticilerin, bu makalenin bulgularından iklim değişikliği başta olmak üzere bilimsel bilginin gerekli olduğu her politika üretme/planlama sürecinde -özellikle kendi bölgeleri için ideal şartları göz önüne alarak- daha güçlü ve sürdürülebilir işbirlikleri yapabilecekleri arayüzler geliştirmek için yararlanabileceği öngörülmektedir.

Makalede iklim değişikliğine ilişkin etkin politika ve bilim-politika arayüzlerinin oluşturulması ve sürdürülmesine yönelik bulgular ele alınarak çalışmanın hem teorik hem de pratik düzeydeki katkısı ortaya koyulmaya çalışılmışır. Ele alınan konularla ilişkili olarak, gelecekte yapılabilecek bir çok araştırma alanı ve konunun olduğu görülmüştür. Bunlardan önde gelenlerinden biri, bilim-politika arayüzlerinde KA uzmanlarıyla işbirliği yapan bilgi üreticilerle gerçekleştirilecek bir çalışmadır. Bilgi üreticileri perspektifine dayalı bir arayüz değerlendirmesi, bu makaleye konu olan çalışmanın kapsamı dışında kalan, dolayısıyla arayüzlerin burada değinilmemiş boyutlarının anlaşııması açısından değerli görülmektedir. Bir başkası ise aynı yereli paylaşan farklı kurumların iklim değişikliğine dair bilim-politika arayüzlerinin çalışılmasıdır. Burada özellikle iklim değişikliğine ilişkin politika ve uygulamaları ile öne çıkan İzmir Kenti Büyükşehir Belediyesi'nin bilim-politika arayüzlerine dair yapılacak çalışma önem taşımaktadır. Bunun paralelinde ulus ve ulusaltı (bölgesel ve yerel) ölçekler arasındaki etkileşime ilişkin bulguların da elde edilebileceği merkezi yönetim - yerel yönetim iklim değişikliği politikası bilim-politika arayüzleri de bir çalışma konusu olabilir. Yine, özellikle İzmir Kenti gibi iklim değişikliğini politikanın ana konularından biri haline getiren yerellerde "ortak-üretim" kavramı çerçevesinde aktör-ağ çalı̧ması bağlamında yapılacak bir bilim-politika arayüzü çalışması hem ilginç hem de bu konuda daha başarılı performans sergilemiş yerellerin daha iyi anlaşılmasını sağlayan sonuçlar sunabilir. Bunun yanında, iklim değişikliğine veya diğer konulara yönelik bilim-politika arayüzlerinin farklı KA’larda ya da başka politika geliştirici/karar verici kurumlarda nasıl kurulduğunu ve sürdürüldüğünü araştırmak da bilim-politika arayüzlerinin Türkiye'de farklı kurumlarda nasıl ele alındığını ortaya koyabilecektir. Ayrıca, benzer konulara ilişkin Türkiye'de ve farklı ülkelerde kurulan bilim-politika arayüzlerinin karşılaştırmalı olarak incelenmesi, sosyo-ekonomik ve kültürel koşulların bilim-politika arayüzleri üzerindeki etkisinin anlaşılmasına katkı sağlayacaktır. Son olarak, bu makale bilim-politika arayüzlerini iklim değişikliği konusu üzerinden ele almış olsa da, genel itibarı ile bilim-politika arayüzlerinden bilimsel bilginin önem taşıdığı her alanda yararlanılabileceği vurgulanmalıdır. Günümüzde aciliyet arz eden kamu sağlığı ve iklim değişikliği başta olmak üzere, hemen her konuda geliştirilen politikalarda bilimsel bilginin politika üretim sürecine nasıl aktarıldığını bilim-politika arayüzleri üzerinden çalışmak ve sistematik olarak incelemek mümkündür.

\section{KAYNAKLAR}

Abadie, L. M., Saim de Murieta, E., Galarraga, I. (2016). Climate Risk Assessment under Uncertainty: An Application to Main European Coastal Cities. Frontiers in Marine Science, 3, 1-13.

Adaman, F., Arsel, M. (2016). Climate Policy in Turkey: A Paradoxical Situation?. L'Europe en Formation, (2), 26-38.

Beck, S. (2016). Knowledge Co-Production: Lures and Pitfalls [Webinar]. The Integrated Assessment Society. Erişim Adresi: https://www.tiasweb.info/wp-content/uploads/2016/06/KnowledgeCoProduction_Lures_and_Pitfalls_S_Beck.pdf (Erişim Tarihi: 13.02.2021).

BMÇP. (2017). Strengthening the Science-Policy Interface: A Gap Analysis. Nairobi.

BMÇP. (2014). The Adaptation Gap Report 2014. Nairobi.

Bulkeley H. (2011) Cities and Subnational Governments. J.S. Dryzek, R.B. Norgaard, D. Schlosberg (Ed.), Oxford Handbook of Climate Change and Society içinde (ss. 464-478). Oxford University Press, New York, NY.

Bultitude, K., Rodari, P., Weitkamp, E. (2012). Bridging the Gap Between Science and Policy: The Importance of Mutual Respect, Trust and the Role of Mediators. Online Journal of Science Communication, 11(3), 1-4.

Choi, B. C., Li, L., Lu, Y., Zhang, L. R., Zhu, Y., Pak, A. W., Little, J. (2016). Bridging the Gap Between Science and Policy: An International Survey of Scientists and Policy Makers in China and Canada. Implementation Science, 11(1).

Compston, H., Bailey, I. (Ed.). (2008). Turning Down the Heat: The Politics of Climate Policy in Affluent Democracies. Springer.

Cortner, H. J. (2000). Making Science Relevant to Environmental Policy. Environmental Science \& Policy, 3(1), 21-30.

Dilling, L., Lemos, M. C. (2011). Creating Usable Science: Opportunities and Constraints for Climate Knowledge Use and Their Implications for Science Policy. Global Environmental Change, 21(2), 680-689.

Dunn, G., Bos, J. J., Brown, R. R. (2018). Mediating the Science-Policy Interface: Insights from the Urban Water Sector in Melbourne, Australia. Environmental Science \& Policy, 82, 143-150.

Edelenbos, J., Van Buuren, A., Van Schie, N. (2011). Co-Producing Knowledge: Joint Knowledge Production Between Experts, Bureaucrats and Stakeholders in Dutch Water Management Projects. Environmental Science \& Policy, 14(6), 675-684.

Erbil, T., Erbil, A. Ö. (2019). Türkiyéde Bölgesel Kalkınma Ajanslarının 2010-2017 Yllları Arasında İklim Değişikliğine Yönelik Faaliyetleri Üzerine Bir İnceleme. Planlama Dergisi, 29(1), 10-22.

Gedikli, B., Balaban, O. (2018). An Evaluation of Local Policies and Actions that Address Climate Change in Turkish Metropolitan Cities. European Planning Studies, 26(3), 458-479.

Gieryn, T. F. (1995). Boundaries of Science. G. E. Markle, S. Jasanoff, J. C. Petersen, T. Pinch (Ed.), Handbook of Science and Technology Studies içinde (ss. 393-443). Sage Publications.

Guston, D. H. (1999). Stabilizing the Boundary Between US Politics and Science: The role of the Office of Technology Transfer as a Boundary Organization. Social Studies of Science, 29(1), 87-111.

Haug, C., Rayner, T., Jordan, A., Hildingsson, R., Stripple, J., Monni, S., \& Berkhout, F. (2010). Navigating the Dilemmas of Climate Policy in Europe: Evidence from Policy Evaluation Studies. Climatic Change, 101(3), 427-445.

Hegger, D., Lamers, M., Van Zeijl-Rozema, A., Dieperink, C. (2012). Conceptualising Joint Knowledge Production in Regional Climate Change Adaptation Projects: Success Conditions and Levers for Action. Environmental Science \& Policy, 18, 52-65.

Hering, J. G. (2016). Do We Need “More Research" or Better Implementation Through Knowledge Brokering?. Sustainability Science, 11(2), 363-369.

IPCC. (2007). Climate Change 2007: Synthesis Report. Contribution of 
Working Groups I, II and III to the Fourth Assessment Report of the Intergovernmental Panel on Climate Change [Core Writing Team, Pachauri, R.K and Reisinger, A. (eds.)]. IPCC, Geneva, Switzerland, 104.

IPCC. (2014) Climate Change 2014: Impacts, Adaptation, and Vulnerability. Part A: Global and Sectoral Aspects. Contribution of Working Group II to the Fifth Assessment Report of the Intergovernmental Panel on Climate Change [Field, C.B., V.R. Barros, D.J. Dokken, K.J. Mach, M.D. Mastrandrea, T.E. Bilir, M. Chatterjee, K.L. Ebi, Y.O. Estrada, R.C. Genova, B. Girma, E.S. Kissel, A.N. Levy, S. MacCracken, P.R. Mastrandrea, and L.L.White (eds.)]. Cambridge University Press, Cambridge, United Kingdom and New York, NY, USA.

Iyalomhe, F., Jensen, A., Critto, A., \& Marcomini, A. (2013). The SciencePolicy Interface for Climate Change Adaptation: The Contribution of Communities of Practice Theory. Environmental Policy and Governance, 23(6), 368-380.

İSTKA. (2014). 2014-2023 İstanbul Bölge Planı. Erişim Adresi: https:// www.istka.org.tr (Erişim Tarihi: 28.07.2020).

İSTKA. (2019). 2019 Yllı Faaliyet Raporu. Erişim Adresi: https://www.istka.org.tr (Erişim Tarihi: 28.07.2020).

İZKA. (2014). 2014-2023 İzmir Bölge Planı. Erişim Adresi: http://www. izka.org.tr (Erişim Tarihi: 28.07.2020).

İZKA. (2019). Endüstriyel Simbiyoz Yerel Paydaş Çalıştayı Gerçekleştirildi. Erişim Adresi: http://www.izka.org.tr/haberler/endustriyel-simbiyoz. html (Erişim Tarihi: 01.08.2020).

İZKA. (2020a). 2020 Çalışma Programı. Erişim Adresi: http://www.izka. org.tr (Erişim Tarihi: 28.07.2020).

İZKA. (2020b). Kaynak Verimliliği İçin Atıktan Hammaddeye Dönüşüm. Erişim Adresi: http://www.izka.org.tr/tr/kaynak-verimliligi (Erişim Tarihi: 01.08.2020).

İZKA. (2021). Yeşil Büyüme. Erişim Adresi: https://izka.org.tr/yesil-buyume/ (Erişim Tarihi: 10.02.2021).

İZKA ve TTGV. (t.y.). İzmir Eko-Verimlilik (Temiz Üretim) Programı. Erişim Adresi: https://en.ttgv.org.tr/content/docs/izmir-eko-verimlilikprogrami-brosuru.pdf (Erişim Tarihi: 06.03.2021).

Jacobson, N., Butterill, D., Goering, P. (2004). Organizational Factors that Influence University-Based Researchers' Engagement in Knowledge Transfer Activities. Science Communication, 25(3), 246-259.

Jasanoff, S. (1994). The Fifth Branch: Science Advisers as Policymakers. London \& Cambridge, MA: Harvard University Press.

Jasanoff, S. (Ed.) (2004) States of Knowledge: The Co-Production of Science and the Social Order. London: Routledge.

Jasanoff, S. (2011). Cosmopolitan Knowledge: Climate Science and Global Civic Epistemology. J.S. Dryzek, R.B. Norgaard, D. Schlosberg (Ed.), Oxford Handbook of Climate Change and Society içinde (ss. 129-143). Oxford University Press, New York, NY.

Maxwell, J. A. (2013). Qualitative Research Design: an Interactive Approach. London: Sage Publications.

Meadow, A. M., Ferguson, D. B., Guido, Z., Horangic, A., Owen, G., Wall, T. (2015). Moving Toward the Deliberate Coproduction of Climate Science Knowledge. Weather, Climate, and Society, 7(2), 179-191.

MedECC. (2018). MedECC side-event during COP24 conference: A science-policy interface on risks of climate and environmental change in the Mediterranean region. MedECC. Erişim Adresi: https://www.medecc. org/1844/ (Erişim Tarihi: 08.02.2021).

Mitton, C., Adair, C. E., McKenzie, E., Patten, S. B., Perry, B. W. (2007). Knowledge Transfer and Exchange: Review and Synthesis of the Literature. The Milbank Quarterly, 85(4), 729-768.

Moser, S. C., Dilling, L. (2011). Communicating Climate Change: Closing the Science-Action Gap. J.S. Dryzek, R.B. Norgaard, D. Schlosberg (Ed.), Oxford Handbook of Climate Change and Society içinde (ss. 161-174). Oxford University Press, New York, NY.

Nature (2019) Scientists worldwide join strikes for climate change. Erişim
Adresi: https://www.nature.com/articles/d41586-019-02791-2 (Erişim Tarihi: 10.02.2021).

Newman, J., Head, B. W. (2015). Categories of Failure in Climate Change Mitigation Policy in Australia. Public Policy and Administration, 30(34), 342-358.

O'Brien, K. (2013). Global Environmental Change III: Closing the Gap Between Knowledge and Action. Progress in Human Geography, 37(4), 587 . 596.

Ramos-Vielba, I., Sánchez-Barrioluengo, M., Woolley, R. (2015). Scientific Research Groups' Cooperation with Firms and Government Agencies: Motivations and Barriers. The Journal of Technology Transfer, 41(3), 558-585.

Ryan, D., Bustos, E. (2019) Knowledge Gaps and Climate Adaptation Policy: A Comparative Analysis Of Six Latin American Countries. Climate Policy, 19(10), 1297-1309.

Smith, A. (2007). Emerging in Between: The Multi-Level Governance of Renewable Energy in the English Regions. Energy Policy, 35(12), 62666280.

Sovacool, B. K., Brown, M. A. (2009). Scaling the Policy Response to Climate Change. Policy and Society, 27(4), 317-328.

Soyer, T. [@tuncsoyer] (2021, Nisan 5). Türkiye Belediyeler Birliği 5. Toplantısı'na kentimiz ev sahipliği yapıyor. [Tweet]. Twitter. Erişim Adresi: https://twitter.com/tuncsoyer/status/1379020953506754564 (Erişim Tarihi: 01.05.2021).

T.C. Cumhurbaşkanlığı. (2018). Bakanlıklara Bağlı, İlgili, İlişkkili Kurum ve Kuruluşlar ile Diğer Kurum ve Kuruluşların Teşkilatı Hakkında Cumhurbaşkanlı̆̆ı Kararnamesi. Erişim Adresi: https://www.mevzuat.gov.tr/ MevzuatMetin/19.5.4.pdf (Erişim Tarihi: 05.04.2021).

Thunberg, G. (2019). Voices Leading the Next Generation on the Global Climate Crisis. Foreign Affairs Committee Subcommittee on Europe, Eurasia, Energy, and the Environment, with the House Select Committee on the Climate Crisis (September 18, 2019). Erişim Adresi: https://foreignaffairs.house.gov/2019/9/voices-leading-the-next-generation-on-theglobal-climate-crisis (Erişim Tarihi: 10.02.2021).

Turhan, E., Cerit Mazlum, S., Şahin, Ü., Şorman, A. H., Cem Gündoğan, A. (2016). Beyond Special Circumstances: Climate Change Policy in Turkey 1992-2015. Wiley Interdisciplinary Reviews: Climate Change, 7(3), 448-460.

UNCCD. (2021). The Science-Policy Interface. Erişim Adresi: https://knowledge.unccd.int/science-policy-interface (Erişim Tarihi: 12.03.2021).

Van den Hove, S. (2007). A Rationale for Science-Policy Interfaces. Futures, 39(7), 807-826.

Van Stigt, R., Driessen, P. P., Spit, T. J. (2015). A User Perspective on the Gap Between Science and Decision-Making. Local Administrators' Views on Expert Knowledge in Urban Planning. Environmental Science \& Policy, 47, 167-176.

Wall, T. U., Meadow, A. M., Horganic, A. (2017). Developing Evaluation Indicators to Improve the Process of Coproducing Usable Climate Science. Weather, Climate, and Society, 9(1), 95-107.

Wan, K., Shackley, S., Doherty, R. M., Shi, Z., Zhang, P., \& Golding, N. (2020). Science-Policy Interplay on Air Pollution Governance in China. Environmental Science \& Policy, 107, 150-157.

Wang, Z., Tan, P. Y., Zhang, T., Nassauer, J. I. (2014). Perspectives on Narrowing the Action Gap Between Landscape Science and Metropolitan Governance: Practice in the US and China. Landscape and Urban Planning, 125, 329-334.

Wyborn, C. (2015). Co-Productive Governance: A Relational Framework for Adaptive Governance. Global Environmental Change, 30, 56-67.

Wyborn, C., Datta, A., Montana, J., Ryan, M., Leith, P., Chaffin, B., Van Kerkhoff, L. (2019). Co-Producing Sustainability: Reordering the Governance of Science, Policy, and Practice. Annual Review of Environment and Resources, 44(1), 319-346. 
Bilgi Notu: Yapılan görüşmeler şu şekilde kodlanmıştır:

İZKA 1: İzmir Kalkınma Ajansı Uzmanı

IZKA 2: İzmir Kalkınma Ajansı Uzmanı

IZZKA 3: İzmir Kalkınma Ajansı Uzmanı

İZKA 4: İzmir Kalkınma Ajansı Uzmanı

IZZKA 5: İzmir Kalkınma Ajansı Uzmanı

İSTKA 1: İstanbul Kalkınma Ajansı Uzmanı

İSTKA 2: İstanbul Kalkınma Ajansı Uzmanı 